\title{
Ethnoecology of pollination and pollinators
}

Knowledge and practice in three societies

Ethnoécologie de la pollinisation et des pollinisateurs : savoirs et pratiques dans trois sociétés

Marie Roué, Vincent Battesti, Nicolas Césard and Romain Simenel

\section{OpenEdition}

\section{Journals}

Electronic version

URL: http://journals.openedition.org/ethnoecologie/2229

DOI: 10.4000/ethnoecologie.2229

ISSN: 2267-2419

Publisher

Laboratoire Eco-anthropologie et Ethnobiologie

\section{Electronic reference}

Marie Roué, Vincent Battesti, Nicolas Césard and Romain Simenel, «Ethnoecology of pollination and

pollinators », Revue d'ethnoécologie [Online], 7 | 2015, Online since 30 June 2015, connection on 03

May 2019. URL : http://journals.openedition.org/ethnoecologie/2229 ; DOI : 10.4000/

ethnoecologie.2229

This text was automatically generated on 3 May 2019.

\section{(c) (†) $\ominus$}

Revue d'ethnoécologie est mis à disposition selon les termes de la licence Creative Commons Attribution - Pas d'Utilisation Commerciale - Pas de Modification 4.0 International. 


\title{
Ethnoecology of pollination and pollinators
}

\author{
Knowledge and practice in three societies \\ Ethnoécologie de la pollinisation et des pollinisateurs : savoirs et pratiques dans \\ trois sociétés
}

Marie Roué, Vincent Battesti, Nicolas Césard and Romain Simenel

1 Since the Convention on Biological Diversity entered into force in 1993, its Article 8(j) has become widely known for its recognition of the « knowledge, innovation and practices of indigenous and local communities». Subsequently, numerous treaties, agreements, and conventions at national and international levels have similarly made reference to the role that indigenous and local knowledge, know-how and practices play in conserving biodiversity. Despite this growing recognition, numerous barriers remain.

In the context of the newly-established Intergovernmental Platform on Biodiversity and Ecosystem Services (IPBES), which has adopted the recognition of indigenous and local knowledge as one of its operating principles, and on the occasion of the first IPBES assessment on pollination and pollinators, four researchers from the Department of People, Nature and Society of the National Museum of Natural History in Paris have come together to produce a paper on local knowledge and pollination. The three case studies presented here are based on long-term field research ${ }^{1}$.

3 When addressing environmental issues, human societies are necessarily at the heart of interactions, problems and solutions, as environmental problems are never purely biological. Even though we see the environment as 'natural', it is in fact the product of a co-evolution between societies, plants and animals. This is all the more the case in our contemporary world that is facing an anthropogenic ecological crisis, an era now often referred to as the Anthropocene. The intimacy of these interactions and co-dependence may be self-evident when it comes to domesticated honeybees, as well as for hand pollination. But they may equally be in operation in the case of wild honeybee colonies, as an exacting knowledge of local honey gatherers about flowering patterns and their 
impact on bee reproduction may also allow them to intervene when opportune and with maximum effect.

This joint paper on indigenous and local knowledge (ILK) about pollination was motivated by a worrisome observation. Even though ILK is increasingly acknowledged and solicited in the conservation arena, they remain for the most part inaccessible and incomprehensible to biologists. Biologists, despite their best intentions, have not been trained to surmount the linguistic and cultural differences between their own culture and that of others. Indeed, the very philosophy of the natural sciences is aimed at apprehending the universal rather than the local. Consequently, the task of bringing ILK into assessments or conservation becomes a shared undertaking involving indigenous peoples and local community members who are holders of this knowledge, and ILK specialists: ethnobiologists, geographers or anthropologists specialised in the ILK field. But even this may not suffice to overcome what Latour (1983) has referred to as the great divide («le grand partage») that hinders the dialogue between biologists and social scientists, each discipline remaining ignorant about the other's methods, concepts, terminologies and journals.

5 Is this divide as insurmountable as it has been in the past? For sure, a new generation of researchers, biologists and environmental managers is emerging that no longer embraces the simplistic image of humans as harmful to nature, which was shared by earlier generations but is now on the wane. Furthermore, in response to broadening societal concern about the environment, universities now regularly include in their interdisciplinary environmental science curricula a space for the social sciences and in some cases local knowledge. Paradoxically, it is often in arenas that are highly specialized in biodiversity conservation that representations of nature without people (i.e. wilderness) persist.

Despite these changes, the persistence of disciplinary barriers is a reason for concern for ILK specialists and ethnobiologists. For more than 50 years, ethnobiologists have made the interface between social systems and ecosystems their principal object of study. We have dedicated ourselves to bridging the gap between the natural and social sciences. So in this world on the look-out for holistic responses, why is there still so little attention to our work? What can be done to make ethnobiological approaches better known and more accessible? How can our long practice of interdisciplinarity and in-depth understandings of the dynamics of indigenous knowledge and practice contribute to identifying betterinformed solutions to human-environment challenges, such as in the case examined here of pollination and pollinators.

7 One way forward is to bring together specialists working in different world regions to publish a paper, not in specialized journals that focus on particular areas or peoples as is often the case in the social sciences, but rather on a specific biological phenomenon - in this case pollination. This approach can facilitate access to ethnobiological data by those on the other side of the 'divide' - biologists and policy-makers. The case studies presented here demonstrate, through a detailed examination of the interrelations between societies and their environment, how people's actions enhance and shape pollination and pollinators:

- In Saharan oases, in-depth knowledge of date palm trees provides the basis for creating diversity, as local people improve fruit quality and invent and maintain varieties by assuming themselves the role of pollinators; 
- In Morocco, a system of production and reproduction based on local knowledge achieves a remarkable symbiosis between honeybees (Apis mellifera) and humans, creating at the same time a unique landscape;

- In Indonesia, local knowledge of the giant honeybee (Apis dorsata), flowers and changing seasons allows honey gatherers to enhance the capacity of bees to produce honey and other products, while facilitating their reproduction.

\section{The Human Pollinator. Date Palms of the Saharan Oases}

Our first case demonstrates the major role that people play since millennia and in a wide variety of societies as pollinators. One example is provided by the cultivation of the date palm (Phoenix dactylifera L., Arecaceae), a diecious anemophilous plant domesticated in the Middle East since ancient times and unknown in the wild. Its cultivation is deeply rooted in human history (Tengberg et al. 2013). Archaeological remains found in the Middle East demonstrate that the culture of dates began around the late 4th millennium B.C.E. (Tengberg 2012). The numerous hypotheses that co-exist today on the origins of its domestication concur on some points but diverge on others (Gros-Balthazard et al. 2013).

Figure 1 : Oasis palm groves are centers of intensive agricultural production. Siwa oasis (Egypt), October $23^{\text {rd }}, 2014$

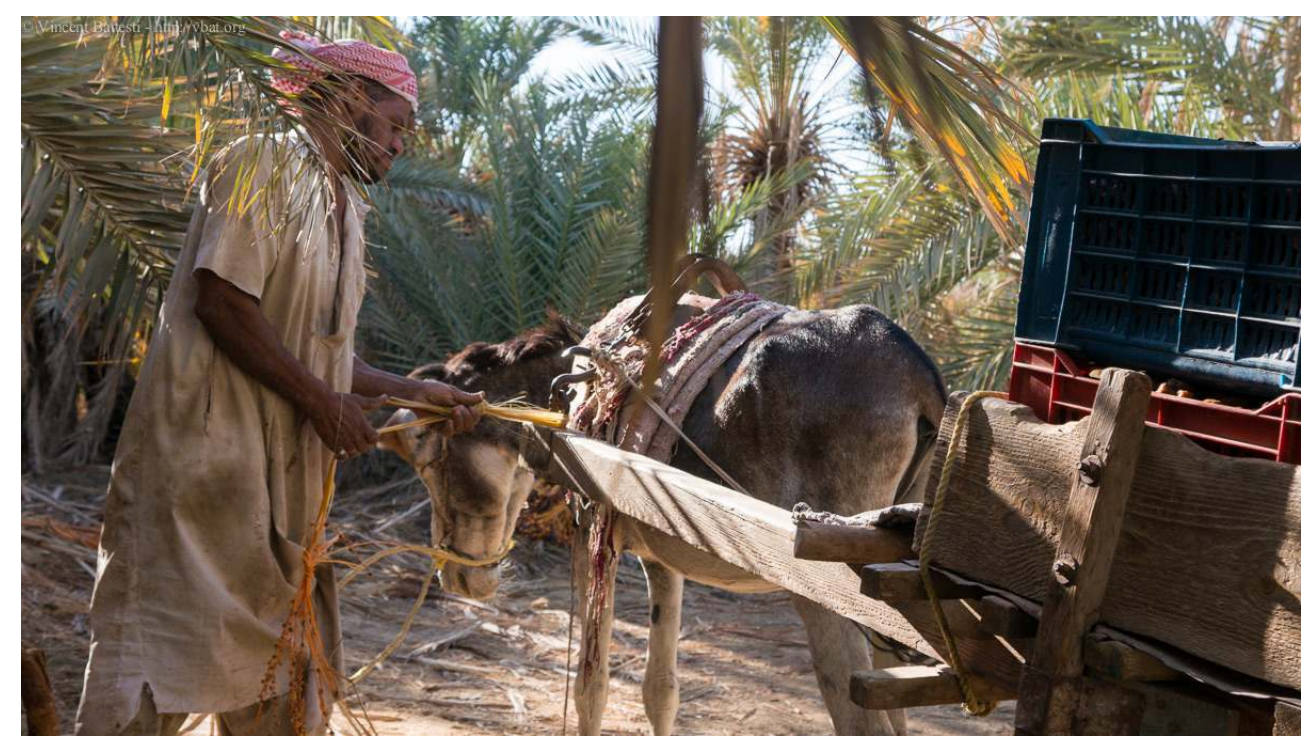

(C) V. BATTESTI

As indicated, Phoenix dactylifera is diecious and anemophilous. Diecious means that every date palm is either male or female (and of course only female plants bear fruit). Anemophilous means that, biologically, this plant has evolved as a wind-pollinated species. Today, Phoenix dactylifera exist only as a cultivated crop, even though some local populations consider it to be wild in their gardens (Tuaregs of the Tassili n'Ajjer, Algeria, see Battesti 2004). The date palm is the main crop of oases. Through the use of every part of this monocotyledon, local communities have learned to cover a large number of their needs (food and drink for livestock and humans, and even alcoholic beverages), basketry, building materials, etc.). It is also the keystone of these very elaborate oasis systems, 
which are artificial agroecosystems that people create and maintain in the desert (Figure 1). Palm trees offer shade and reduce evaporation, allowing other crops to be cultivated and contributing to the unique condition known as the "oasis effect» (Riou 1990). Oases represent one of the best examples of how humanity, through a very complex social and technical organization, domesticates a harsh desert environment and transforms it to produce food.

10 For the oasis system to be efficient in the Sahara, where the scarcity of irrigable lands and manure is a real concern along with the scarcity of water, all oasis populations choose the option of planting and maintaining a sex ratio of female trees of $95-99 \%$. The "natural" sex ratio through sexual reproduction would be 50:50 male and female (about half the seeds are female and the other half male). In order to obtain almost exclusively female trees (but also to ascertain that fruit will be of the desired quality), the date palm growers make use of the asexual reproduction abilities of this plant through the multiplication of its shoots, and restrict nearly completely its sexual reproduction by seeds. Nevertheless, as the primary purpose of date palm cultivation is to harvest dates (Figure 2), effective pollination is a mandatory step to achieve successful fertilization and in fine abundant fruiting. Opting for such an artificial sex ratio requires, however, a replacement for "normal" wind pollination. Oases populations have had to invent hand-pollination as a substitute. In Saharan oases, the process of hand-pollination of the date palm is part and parcel of the knowledge and practices of date palm growers in every garden of the palm groves (Battesti 2005).

Figure 2 : An oasis farmer in the head of a date palm cutting a cluster of dates, Siwa oasis (Egypt), December $5^{\text {th }}, 2013$

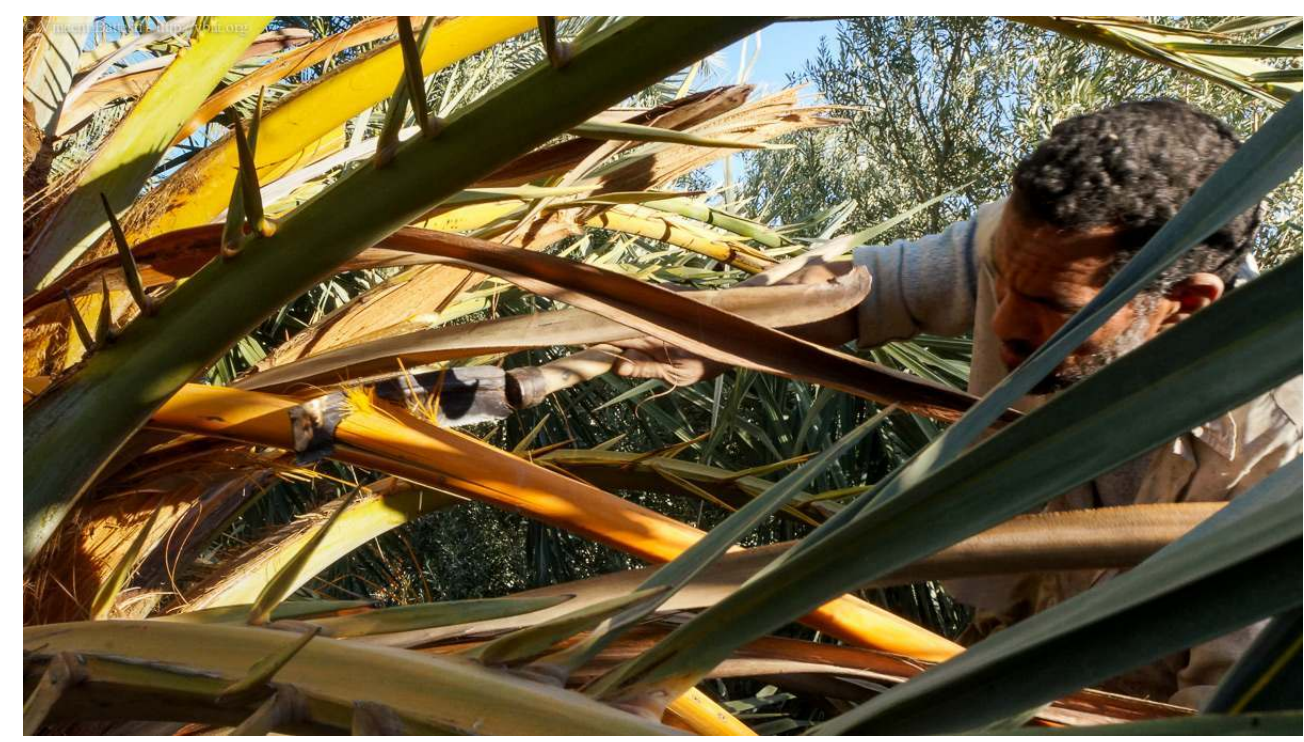

(c) V. Battesti

\section{A process based on knowledge and intense labour}

11 Offsetting the anthropogenic imbalance of the sex ratio of the grove by hand-pollination requires an enormous amount of work. In the date palm groves that feed millions of people in the world, every female palm has to be pollinated: the owners or their workers climb every date palm, sometimes more than once, to deposit pollen inside the female 
inflorescences, still enveloped by deciduous spathes, which will become clusters of dates. This labor is done everywhere, even in the less intensive oases systems managed by nomadic people like the Daza in Chad, who are camel breeders (Baroin \& Pret 1993). The date palm has become so anthropized that in the Jerid oases (Tunisia), local farmers consider the wind to be harmful to pollination and they refrain from pollinating on windy days, judging the temperature to be too low (Battesti 2005).

Figure 3 : The male inflorescence. Preparation of the pollen for hand-pollination of the date palm ( Phoenix dactylifera L.), Siwa oasis (Egypt), March 28 $8^{\text {th }}, 2004$

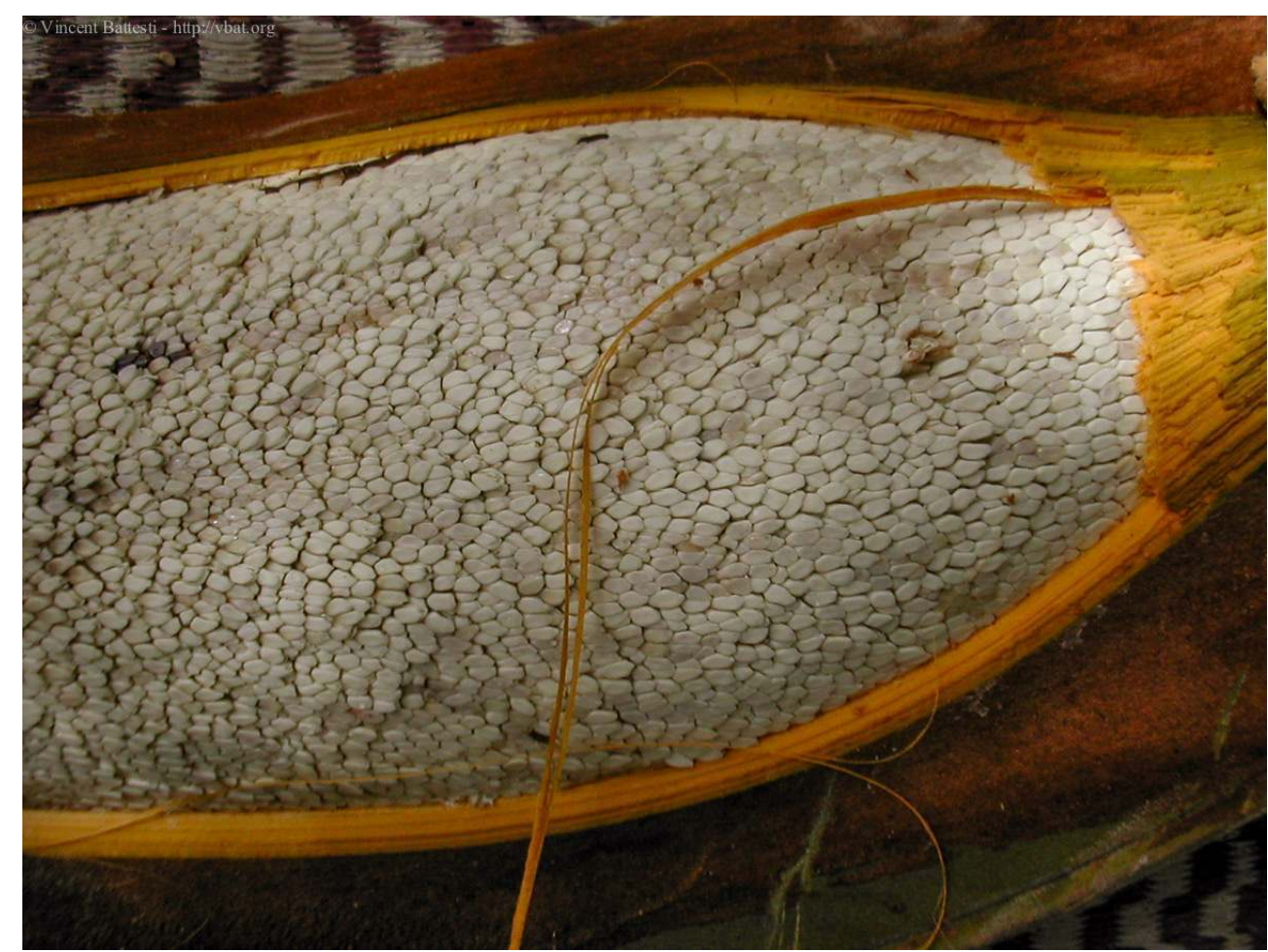

(C) V. BATTESTI 
Figure 4 : Preparation of the pollen for hand-pollination of the date palm (Phoenix dactylifera L.), Siwa oasis (Egypt), March 28 $8^{\text {th }}, 2004$

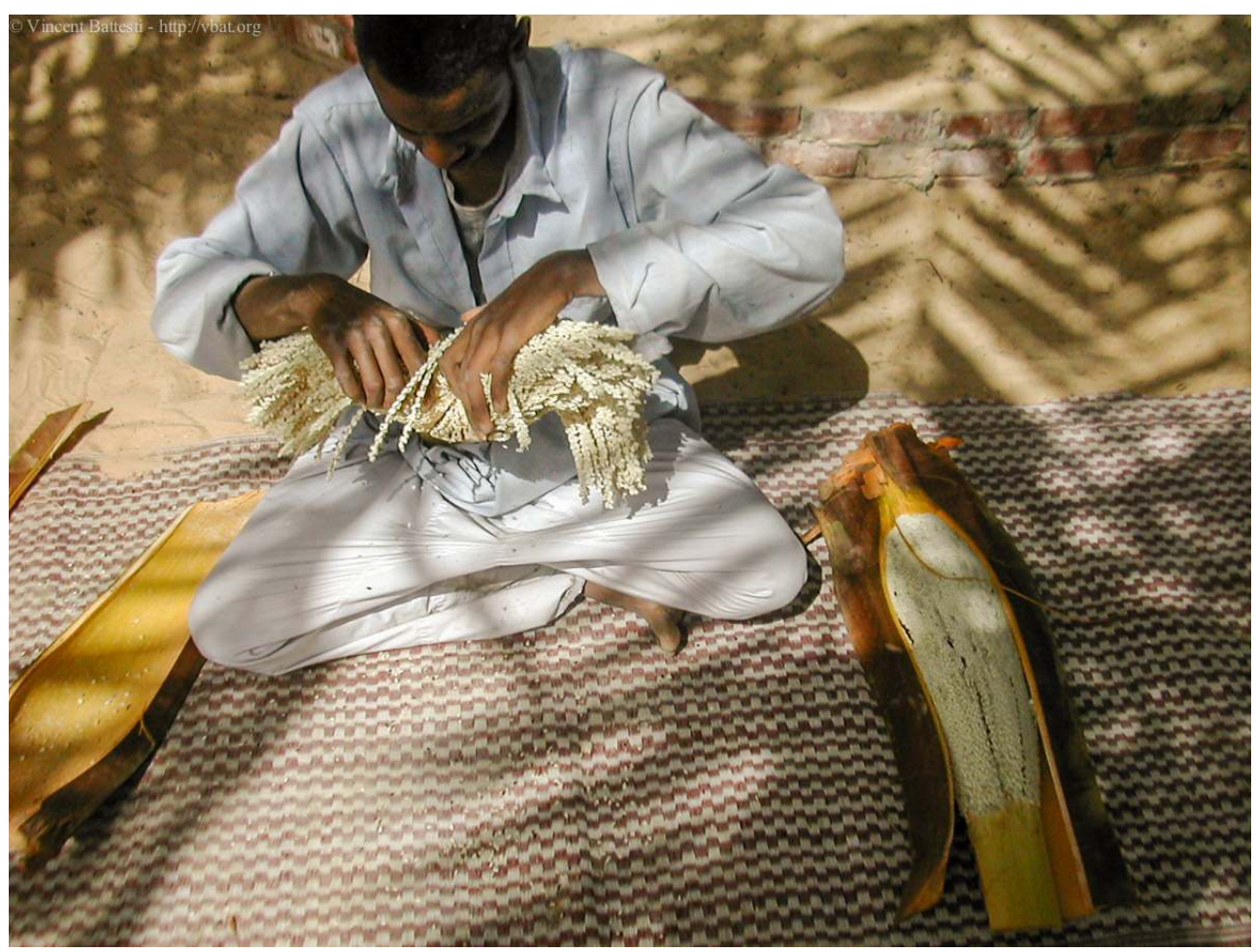

(C) V. BATTESTI

Figure 5 : Preparation of the pollen for hand-pollination of the date palm (Phoenix dactylifera L.), Siwa oasis (Egypt), March 28 ${ }^{\text {th }}, 2004$

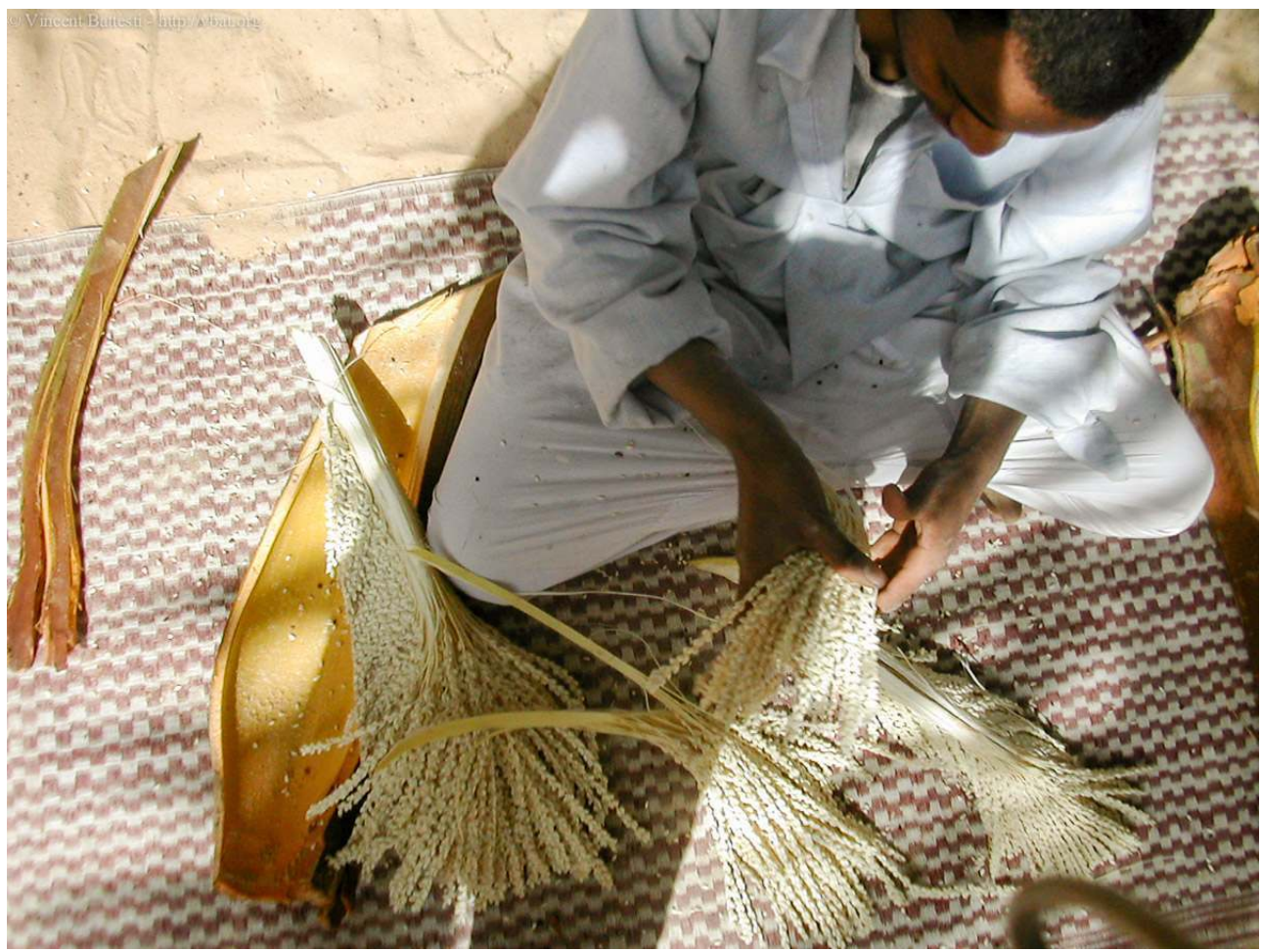

(C) V. BATTESTI 
Figure 6 : Preparation of the pollen for hand-pollination of the date palm (Phoenix dactylifera L.), Siwa oasis (Egypt), March 28 ${ }^{\text {th }}, 2004$

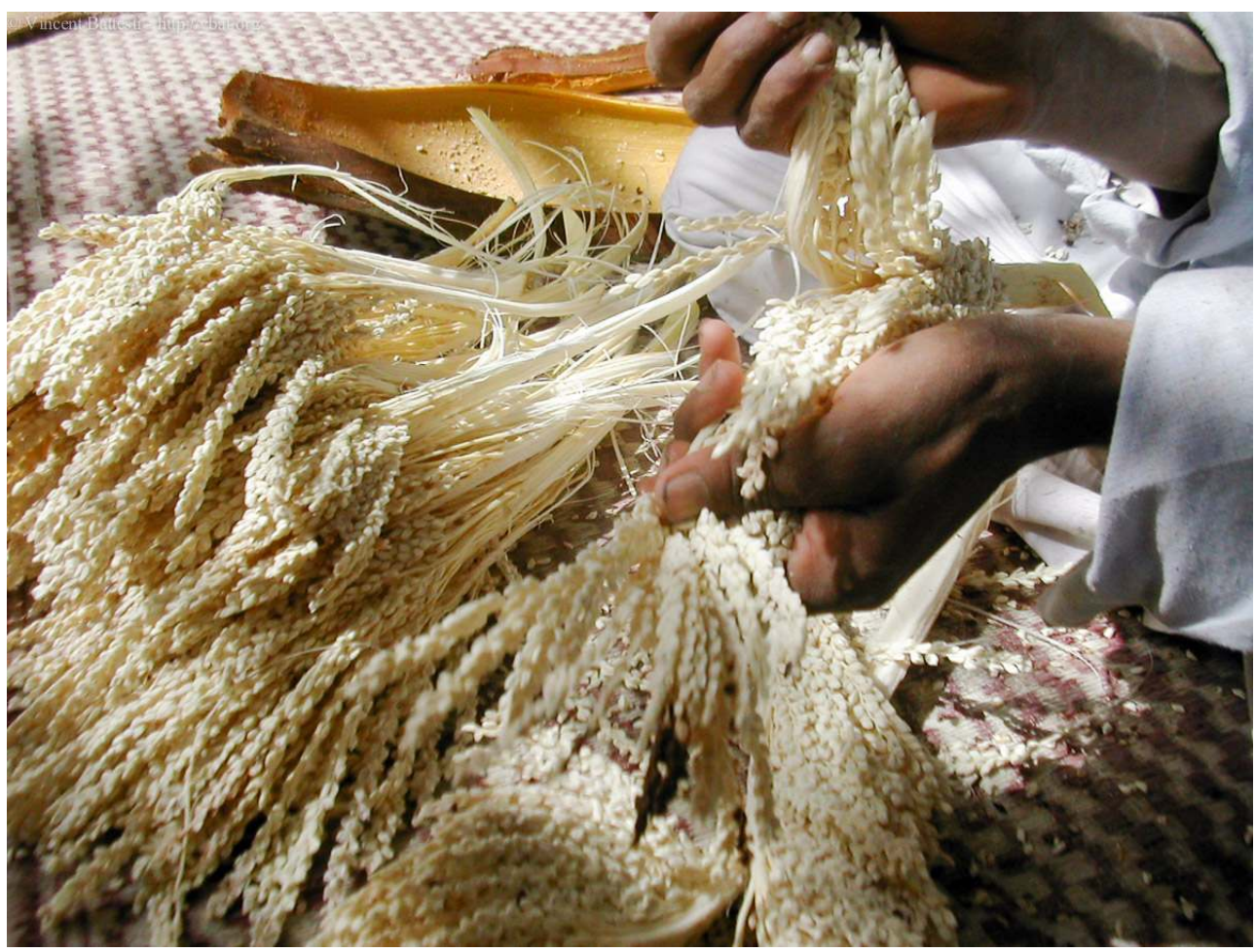

(C) V. BATTESTI

Figure 7 : Preparation of the pollen for hand-pollination of the date palm (Phoenix dactylifera L.), Siwa oasis (Egypt), March $28^{\text {th }}, 2004$

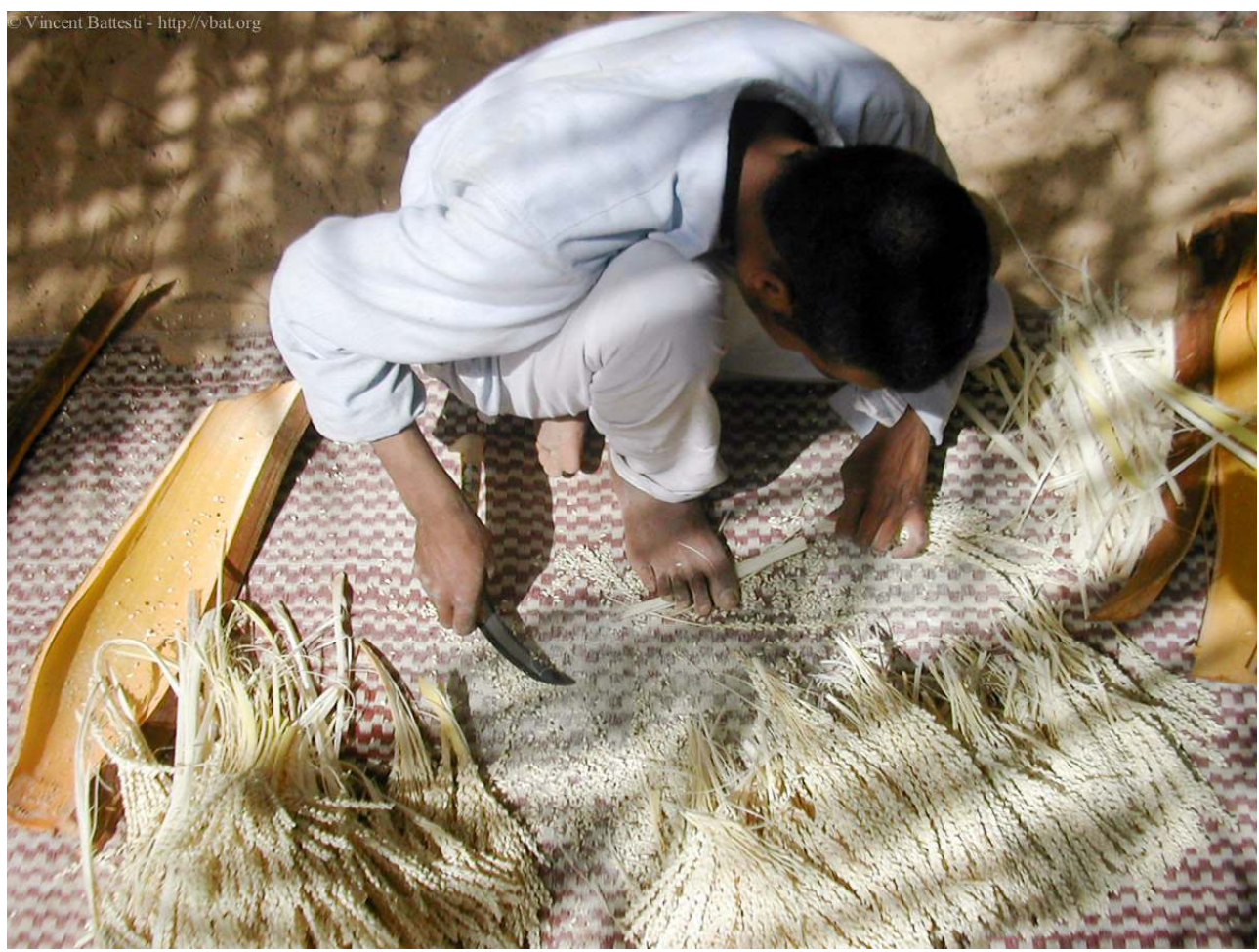

(C) V. BATTESTI 
Figure 8 : Preparation of the pollen for hand-pollination of the date palm (Phoenix dactylifera L.), Siwa oasis (Egypt), March 28 ${ }^{\text {th }}, 2004$

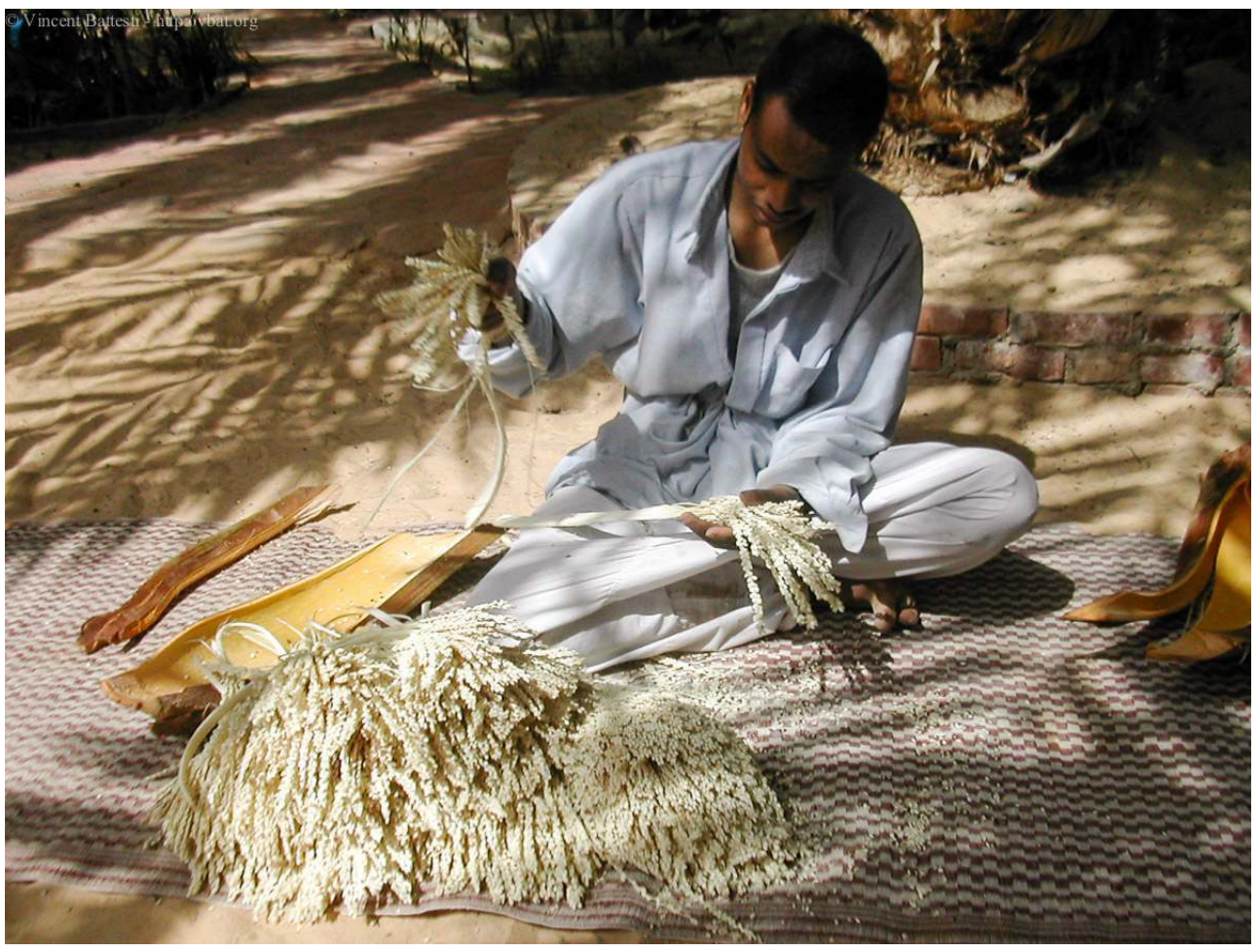

(C) V. BATTESTI

Figure 9 : Preparation of the pollen for hand-pollination of the date palm (Phoenix dactylifera L.), Siwa oasis (Egypt), March $28^{\text {th }}, 2004$

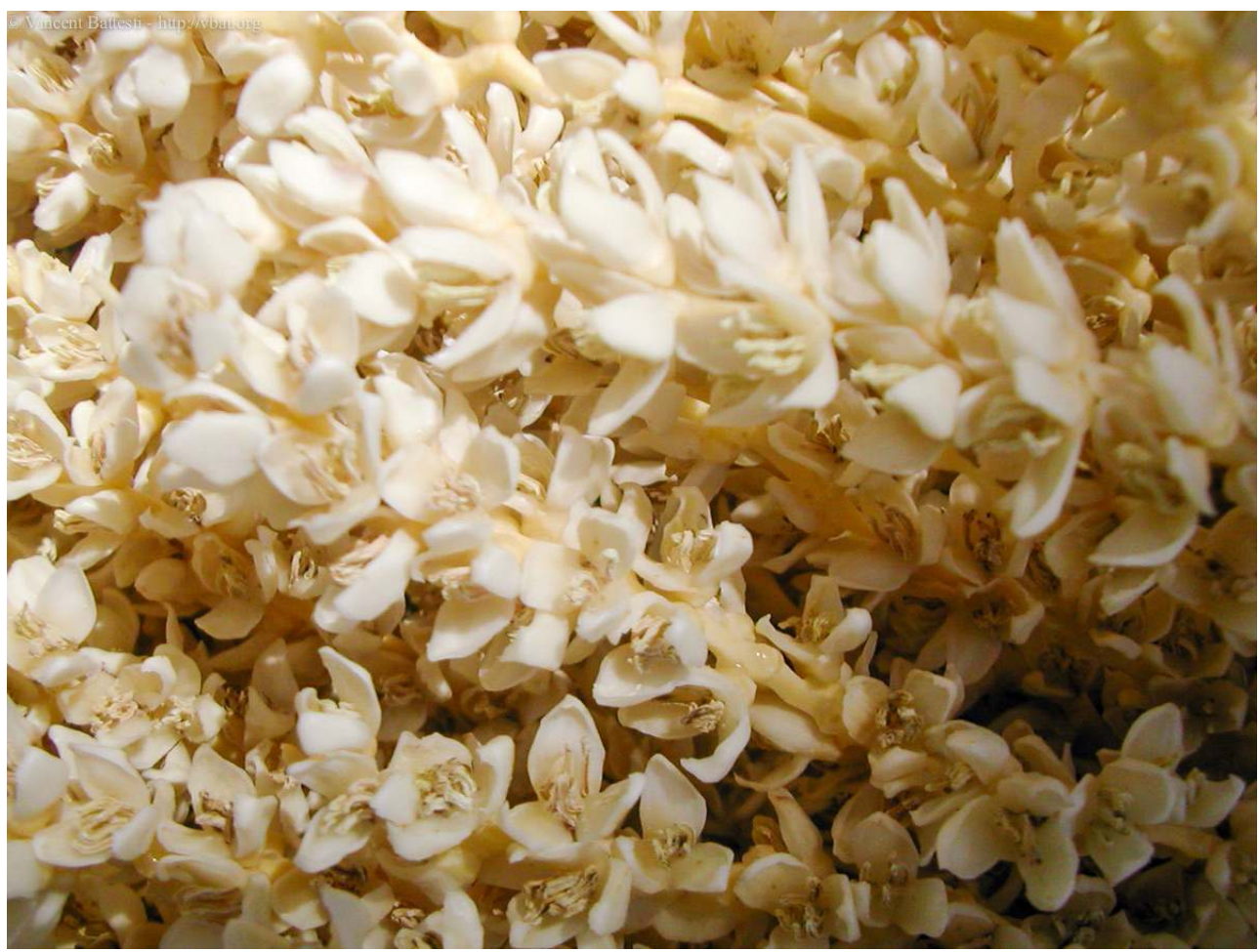

(C) V. BATTESTI 
Figure 10 : A farmer climbing a date palm (Phoenix dactylifera L.) to pollinate its female flowers with the pollen he has prepared, Siwa oasis (Egypt), March $28^{\text {th }}, 2004$

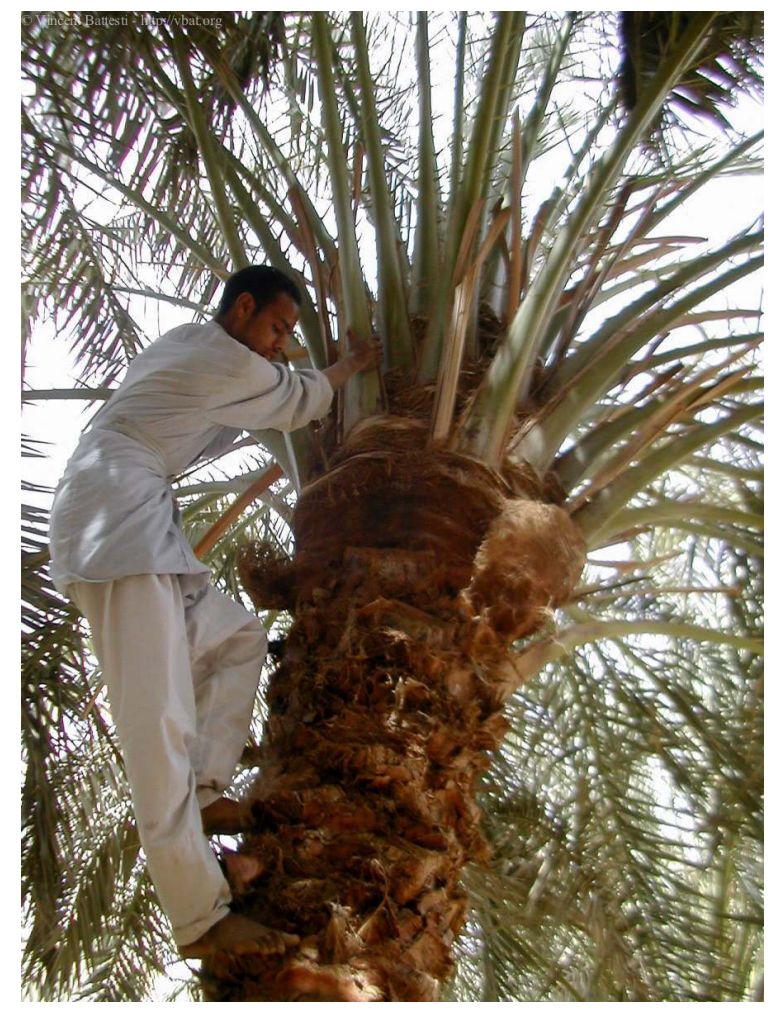

(C) V. Battesti

The first step is to harvest a male inflorescence. In some oases, famers consider that some male trees are better suited than others for some specific varieties of female date palm (for example in the Jerid oases, South Tunisia, Battesti 2005) or that some male trees are more efficient at fertilization, as can be the case with human males (for example in Siwa Oasis, Western Egypt, Battesti 2013). In fact, local knowledge of the reproductive biology of date palms is perhaps more detailed than agronomists have previously thought. Differentiating between types of male palm trees and qualities of pollen makes good sense now that more is known about the "metaxenic effect »: the pollen type has, in some conditions, a significant and direct effect on the quality and maturity of the fruit: some pollen types promote early maturity while others delay ripening. Nixon $(1926,1927)$ and Swingle (1928) were the first to reveal metaxenia, even though the hypothesis was tested throughout the rest of the $20^{\text {th }}$ century with no definitive understanding of the mechanisms (Chao \& Krueger 2007: 1079).

The farmer cuts the whole male inflorescence and then once back on the ground, he separates all its spikelets and lets them dry (Figures 3 to 9). The pollen is ripe when a powder freely escapes from the male flowers. Incidentally, the date palm pollen is also used by the local communities of Jerid oasis region (South Tunisia) to treat nosebleeds and to enhance human virility and the efficiency of human reproduction (eating it would « fortify » the spermatozoids) ${ }^{2}$. In Siwa oasis, people clearly identify pollen as equivalent to (human) sperm. They also enjoy drinking the date palm pollen (if they have a lot) mixed with water and sugar (Figure 11). 
Figure 11 : The male flowers of date palm, harvested to hand pollinate the female date palm, Siwa oasis (Egypt), December $24^{\text {th }}, 2004$

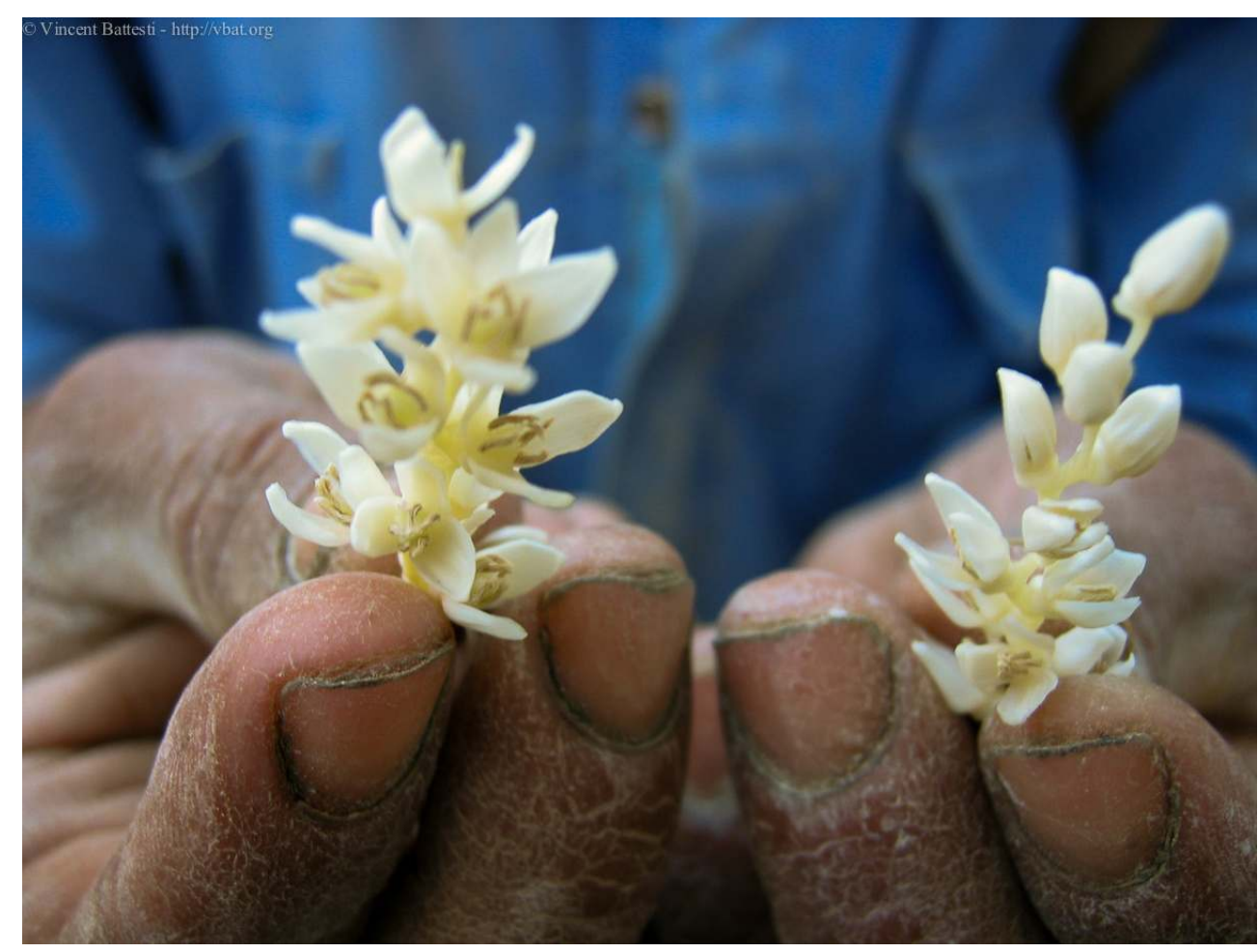

(c) V. Battesti

The oases farmers usually know the springtime chronology of maturation of the different varieties of date palms growing in their garden. They inspect their garden every day during this period to check the opening of the spathes to pollinate them at the right moment. An oases garden in an old palm grove has an average size of roughly a quarter to one hectare with palm tree densities of 200 to 400 per hectare, in addition to the fruit trees or vegetables and fodder below. This means that in their small garden, growers have to climb with their bare feet and hands roughly 150 date palm stipes, up to 20 meters high, once per tree at least, and up to four times for the most valuable ones. They must manage to work their way inside the head of the palms. For that purpose, it is often necessary to remove old palms or sometimes to build what is called a " window », where the spines at the base of the palm rachis have been removed (to enter without risking injury, blindness is not uncommon). The human pollinators have then to complete the opening of each of the inflorescences (up to ten per tree): with their dedicated sickle, they removes the bracts, sometimes thin out some female spikelets to obtain larger fruit, attach a dried male spikelet of pollen, and finally maintain the female inflorescence together with a knotted leaflet. Of the three or more male spikelets used per female inflorescence, one or two are turned upside down to pollinate efficiently in both directions. The knot undoes itself when the cluster of dates begins to form and open (Figure 12). After pollination, two of the three carpels fall; the third develops into a date. If pollination was badly conducted (or not performed), a parthenocarpic fruit, never appreciated and never sold, would grow instead of the fertilized ovary. 
Figure 12 : Remains of a male spikelet in a growing female date inflorescence after human pollination, Siwa oasis (Egypt), May $8^{\text {th }}, 2013$

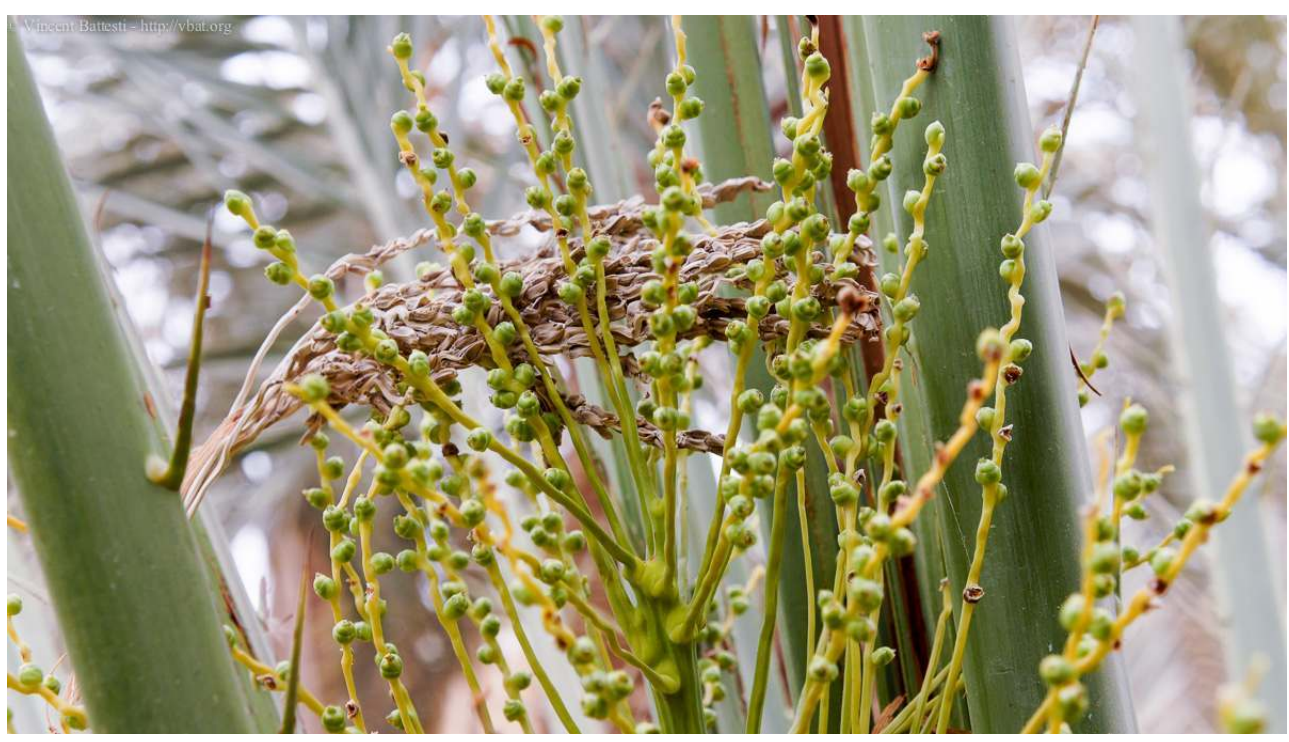

(c) V. BATTESTI

Some variations in this practice may occur in different regions of the old World (see for example Popenoe \& Bennett 1913), but the principle remains the same.

\section{From knowledge to values}

In such an artificial agroecosystem, the sexual act of pollination which is performed is not as simple as dropped pollen, germinating to ovules and inducing fruiting. It requires a volume of knowledge about date palm biology, know-how and practices that become mandatory by the choices made to manage the date palm (Figure 13). Beyond the actions that can be observed from a purely technical perspective, hand pollination is also the pride of a palm grove labor class in either Arabic or Berber-speaking populations of the Sahara: demonstrating fearlessness to climb into the tops of the palm grove canopy is an admired and highly-valued skill. It is also the opportunity for oases farmers, going to each of their date palms to check the opening flowers or to pollinate them, and to sing love songs. In the Jerid oases, these few lyrics are an example of the strong involvement of humans in a pollination that in theory is abiotic:

"The beautiful woman removed her belt [undressed] to sleep [lie beside the man].

She was yellow and turned red [she is now ripe, fertilized]".

17 Direct reference is made to the opening of the floral bracts and the stages of date maturation: from yellow, referred to as beser, to red, known as tamra; the man is the pollen, but also the gardener (Battesti 2005). This song is echoed in Akkadian Mesopotamia where the term for the fertilization process, rakabum, also refers to (or is taken from) the act of fertilizing a woman (Michel-Dansac \& Caubet 2013).

The technique of hand-pollination is documented through iconographic and textual sources, some of which date back to the third millennium B.C.E. (Landsberger 1967). While this interpretation is still debated, the Code of Hammurabi, the Babylonian law code of ancient Mesopotamia dating back to about 1754 B.C.E., seems to offer a consensual textual source for this practice, and we can ascertain that date palm pollination was 
practiced in Mesopotamia as early as the Old Babylonian Period, $20^{\text {th }}$ to $16^{\text {th }}$ centuries B.C.E. (Giovino 2007).

Figure $13:$ In all of the Sahara, the date palm is the main crop and the keystone of oasis systems, Siwa oasis (Egypt), November26 th, 2013

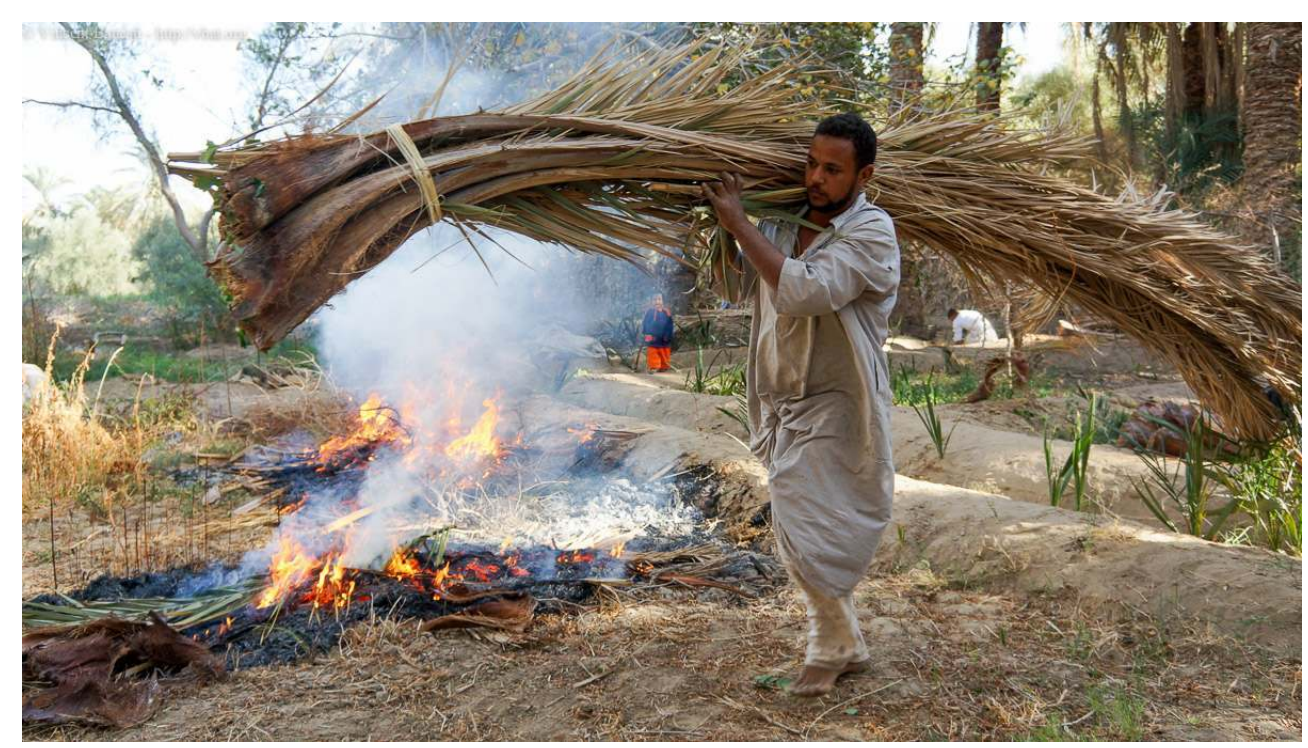

(C) V. BATTESTI

19 Environmental transformation by humankind is an integral part of this socio-ecological relationship. In the case of oasis palm groves, the creation of these fully-artificial ecosystems required local communities to stand in for the natural pollinator, and consequently to create a novel ensemble of knowledge and practices.

\section{Beekeeping and pollination in South Morocco}

In South Morocco, beekeeping is a result of the co-evolution between the Berber groups and a unique agroforestry system centered on the argan tree (Argania spinosa L.) ${ }^{3}$. This agro-ecosystem, shaped during innumerable generations by Berber peasants, covers some 850,000 hectares in the semi-arid regions of southwest Morocco (Simenel 2011). The know-how of beekeepers in these areas is partly based on the manipulation of various types of agricultural lands, beekeeping being part of a larger agroecosystem. Although beekeeping in South Morocco can be qualified as sedentary, it involves a wide variety of habitats, including waterfalls, fields of cereals and argan trees, tree-growing enclosures (arboriculture), monocultures of prickly pears (cactus) and pastoral areas dominated by euphorbia and argan trees.

21 Each spatial unit of this rural territory contributes to some degree towards the domestication of honeybees. Depending on the season and on their own needs, beekeepers can decide to place their hives in one habitat or another in order to collect new swarms, favor honey production and maintain the good health of colonies, their rapid multiplication, but also their protection in the event of severe drought. Colonies of domestic bees play an essential role in pollinating the argan trees.

The placement of the beehives in this mosaic of cultivated areas is not haphazard. Maintaining bee hives near their homes in the prickly pear cactus groves or installing 
them in a tree-growing area surrounded by fields, enhances the pollination of the argan trees located in agricultural zones. From both of these locations, the bees are able to cover an extensive area from the homes to the argan forests. Unlike the forest areas, the need for pollination is particularly important in the agricultural fields where the number of argan trees bearing fruit is high. According to beekeepers, honeybee pollination of argan trees allows for a better fruit production with up to two harvests per year. Argan trees growing in fields produce most of the harvested fruits that are transformed into argan oil, an essential ingredient for local subsistence. The pollination of forest argan trees is ensured by honeybee colonies living in hives situated in arboricultural areas, as well as by wild colonies nesting in cliffs, in addition to other pollinators.

Honeybees are not only collecting nectar and pollen from agricultural lands. They also collect a significant variety of organic materials from other sources that are essential for the reproduction of the colony and its good health. Beekeepers interpret the various aspects of the life cycle of the honeybees, taking into account the uses that the bees make of the plant products collected. They then evaluate their effects on the development of the hive and the behavior of its inhabitants. The availability of a diversity of plant materials stems from a remarkable spatio-temporal concordance between human practices and bee activities.

Figure 14 : An oasis with a field in bloom, Imi Ougouni, 2009

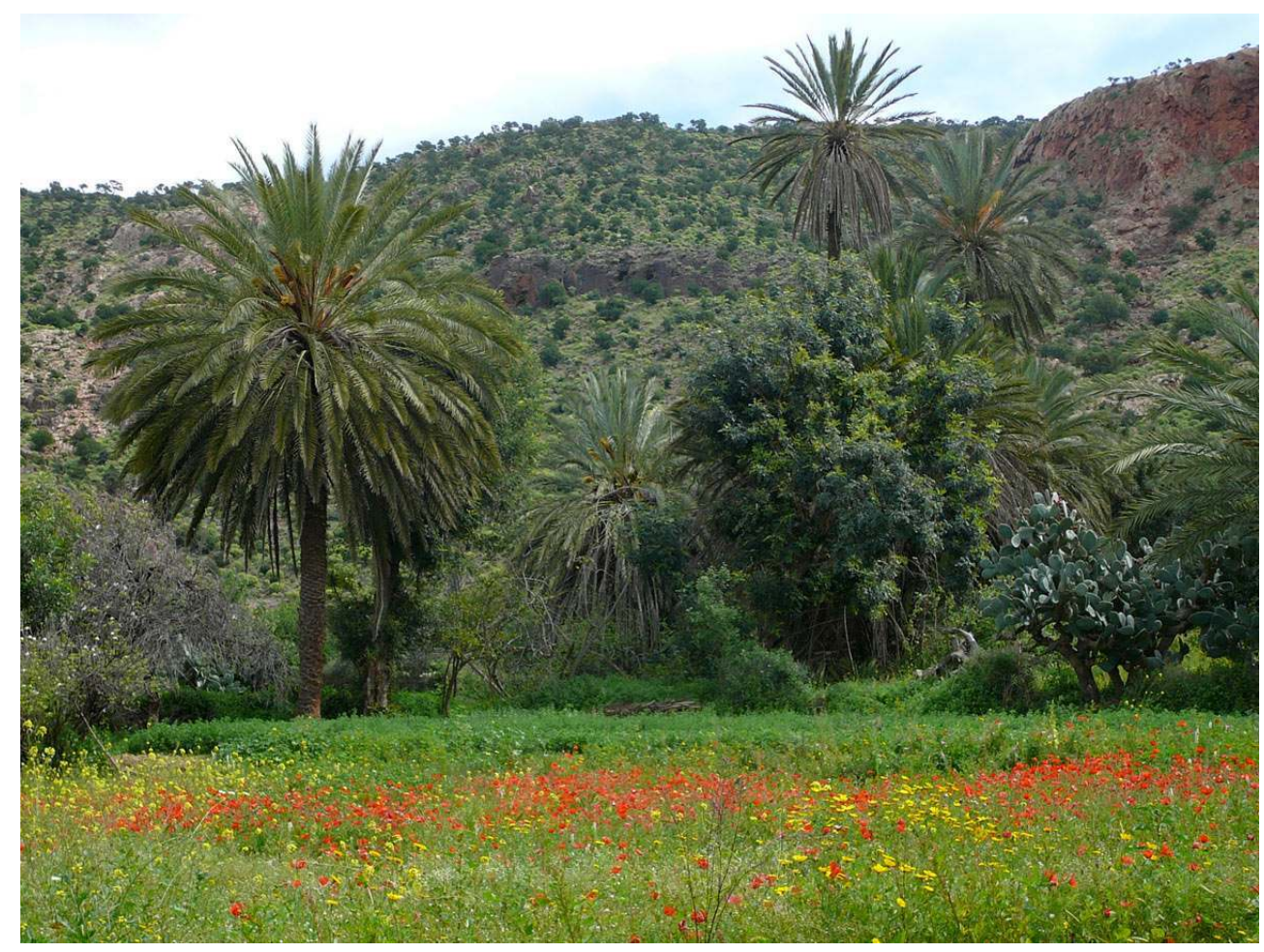

THE MOUNTAINS IN THE BACKgROUND ARE COVERED WITH EUPHORBIA AND ARgAN TREES

(C) Y. AUMEERUDDY-THOMAS

\section{Ecological knowledge about pollination and pollinators}

According to the beekeepers of South Morocco, some plants play an essential role in the development of the bee colony - from brood development to swarming - and thus of their 
beekeeping practice. We now present and try to classify the local knowledge and practices of beekeepers according to the different effects and uses of plant products that are harvested by bees. Four main categories can be distinguished (see Table 1 in Simenel et al. 2015):

\section{Control of varroa}

Varroa is one of the causes of Colony Collapse Disorder (CCD). Berber-speaking beekeepers report that their honeybees are able to reduce the impacts of parasite invasions by using certain plant products that are transformed into propolis by the bees. These products include a wide variety of substances, from euphorbia latex to Ononis exudate, in addition to the sap of Senecio anteuphorbium. According to beekeepers, the more the harvested latex is "peppery" (harr in the local language), the more they are effective against varroa. Several plant species release sap when their surface is scored. Beekeepers report that bees make an incision in the skin of fruit (Argania spinosa L.) or at the base of leaves (Periploca laevigata Aiton) in order to trigger a flow of latex that they then harvest. Some herbaceous species, on the other hand, secrete exudates that are directly accessible on the plant's surface. By moving their hives to sites where the aforementioned plants are present in high density, beekeepers are able to inhibit the action of the parasites and to some extent control their invasion. They also use certain plants such as thyme and artemisia to smoke the colonies, and in doing so reduce the frequency of chemical treatments to control varroa. These observations and practices demonstrate the intimate and extensive knowledge that beekeepers possess about bees and their behavior and ecology.

\section{The health and hygiene of the beehive}

Beekeepers attribute the good health of their hives to a regular supply of nutrients, water and plant substances to fight against varroa mites and other parasites. During flowering periods, they observe the foraging behavior of the bees and underscore the importance of certain plant species in the feeding of the brood. The nectar collected in certain flowers, such as pomegranate, or the sap from some leaves, such as the fig tree, are said to have special properties. Beekeepers explain that bees may also use some latexes and resins directly, without being transformed (i.e. without processing) to control varroa.

\section{Increasing the frequency of swarming by stimulating colony growth.}

According to beekeepers, exudates harvested by bees from certain plant species tend to increase the frequency of swarming. The effect of these plants is first noticed by the beekeepers as an increase in the aggressiveness of the bees when the hives are visited. For example, the flowers of the asphodel (Asphodelus tenuifolius Cav.) are recognized as a nectar source that stimulates the laying of the queen, hence its local nickname of « viagra for bees ». When these plants are in flower, the beekeepers note an increase in the frequency of swarming, which they attribute to the stimulating effect of these plants on colony reproduction and growth. 


\section{Decreasing swarming frequency by delaying the departure of the old queen.} specific locations, the beekeepers maintain a direct control on the reproduction of bees and the physiological rhythms associated with their food, a major condition for their domestication. Thus it is through the territory that the bee is domesticated because the beekeepers, by playing on the multifunctionality of spaces in terms of plant diversity, controls the cycle of life and the production and reproduction of the bee.

Figure 15 : Ait Baamran beekeeper with his beehives, Taloust 2004

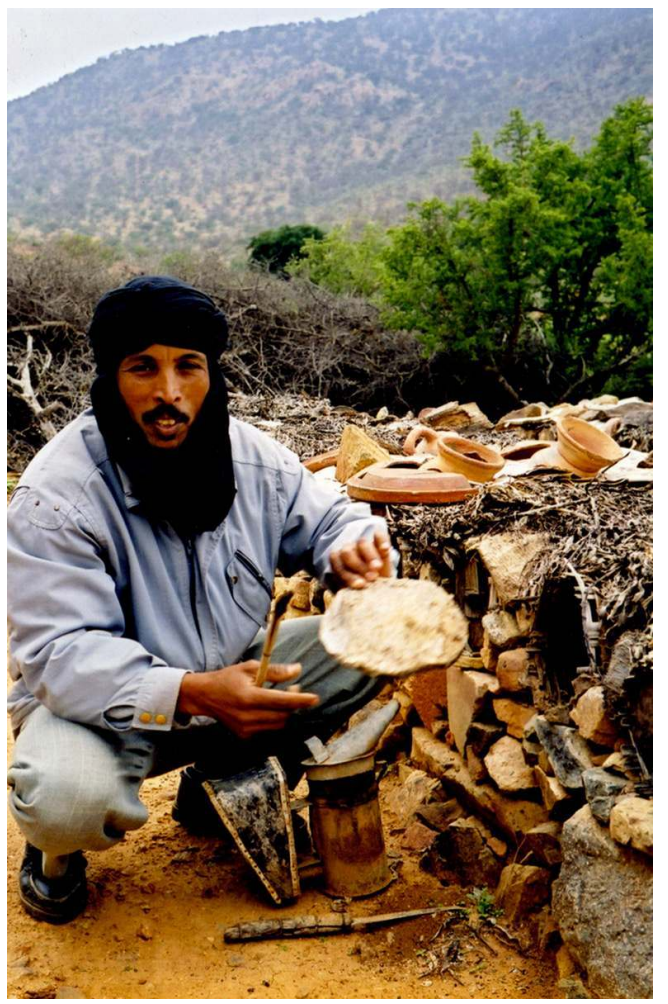

(C) R. SIMENEL 


\section{Farming forest honey in Indonesia: Anticipating bee arrivals and harvest times by knowing your flowers}

31 In Indonesia, knowledge related to flowers is fundamental to the organization of forest honey harvesting activities i.e. honey hunting and beekeeping. It allows the harvesters to prepare for the coming of the swarms and once the bees are settled to decide when to collect honey on the comb. Honey collectors associate the migration of colonies of the giant Asian honeybee (Apis dorsata) to their nesting sites to general flowering (GF) events, a well-known ecological phenomenon in Southeast Asia in which most trees of most tree species flower simultaneously at more or less random times of the year (Appanah 1985, Sakai 2002). This third case study introduces local knowledge associated with honeybees and blossoms in two regions of Indonesia, where honey harvesting on an artificial structure, called rafter beekeeping, is practiced along with honey hunting on tall trees.

\section{The giant honeybee and the rafter technique}

The Asian giant honeybee, Apis dorsata, is one of the largest species of the genus Apis. The colonies build nests in the open-air, hanging underneath the branches of large trees, on rock cliffs or sometimes on buildings. Their nest is formed by a single vertical comb which can attain one to two meters in length and a meter and half in height. Colonies are gregarious and one can find more than a hundred nests at the same site. Like its cousin the "domesticated" European and African honeybee, a colony contains a single queen and several males during the breeding season. A single comb can contain up to 10,000 workers grouped in several layers on its surface. The species is known to collectors for its aggressiveness and for the great mobility of its swarms. Indeed, colonies often migrate, either according to the season, or in response to blooms or disruptions that they may experience. On these occasions, the bees abandon their nest and may fly for several kilometers in search of new sources of food. It has been observed by honey harvesters as well as by scientists (Neuman et al. 2000, Paar et al. 2000) that, after several months or even a year or two, bee colonies return to settle on the same branches of the same tree.

Honey and bee broods of Apis dorsata represent essential energy foods, as well as additional sources of income from the sale of any excess. However, the honey of the Asian giant honeybees remains a forest resource that is difficult to exploit. Throughout the geographic range of the species, in South Asia and Southeast Asia, honey hunters take significant risks by harvesting honey from nests that are often difficult to access. The harvesting of honey on trees continues to be practiced intensively, but accidents are not uncommon. As a result, a form of "beekeeping" and management of A. dorsata swarms has developed in certain areas, particularly in Indonesia (De Vries 1990, Hadisoesilo 2001, Césard 2015). The technique known as the "rafter" technique consists of setting up on the ground or at ground level a slightly inclined support, a hardwood plank or a tree trunk for instance, under which the bees establish their colony by building their single-comb nest. The nature of the installation and its location serve to attract the bees at the time of their migrations and facilitate the construction of the comb. When conditions are ideal, it may also allow for regular and secure harvests, which in contrast to the collection of honey from tall trees, are easily accessible. Knowledge of bee foraging sites and of the 
timing, location and types of flowers in bloom, along with their production of nectar and pollen, is particularly important for this technique.

Figure 16 : An Apis dorsata colony settled underneath a honey trunk (sunggAU), Belitung 2011

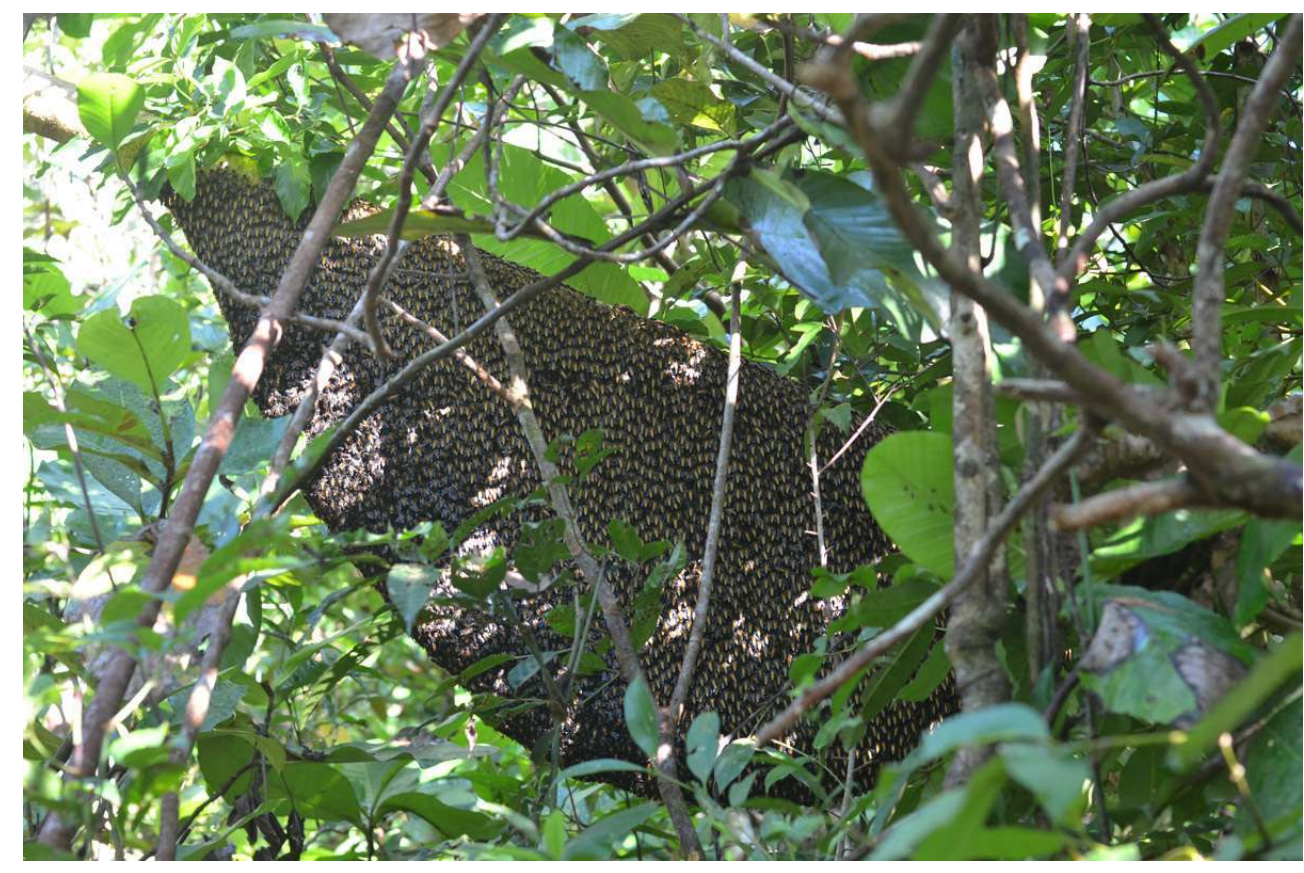

(c) N. Césard

\section{Following flowers to prepare for arrival of the swarms} within the same geographical area, they often vary according to their abundance. In Danau Sentarum National Park, in the western part of the island of Borneo, the region's lakes are almost continuously replenished by rainfall, with the exception of a short period between June and August during which they dry out, some completely. This seasonality has major consequences for the vegetation and fauna. The end of the dry season is followed from December to February by a rise in water levels which leads to bud induction and to massive and successive blooms. This period is vital to the honeybees and sees the arrival of numerous colonies. In the flooded forests, many species of trees are then in flower, of which around 20 species are important for honey production such as the masung (Syzygium claviflora) and the tahun (Carallia bracteata) trees (see Mulder et al. 2000).

Further west, close to the east coast of Sumatra, on the island of Belitung, the type of honey harvested also changes depending on areas and periods of the year. In the coastal forests, dominated by small-sized trees, the gelam tree (Melaleuca leucadendron) is said to be prized by honeybees for its nectar and the jemang (Rhodomnia cinera) and the betor ( Calophyllum pulcherrirum) trees for their pollen. In the island's interior, the bitter honey of the pelawan trees (Tristania obovata and $T$. whiteana) is the most sought after. Unfortunately, the forests which shelter these trees have been massively converted in the last 10 years into oil palm plantations and other agricultural activities.

Revue d'ethnoécologie, 7 | 2015 
Figure 17 : Flowers of the gelam tree (Melaleuca leucadendron). Belitung, 2013

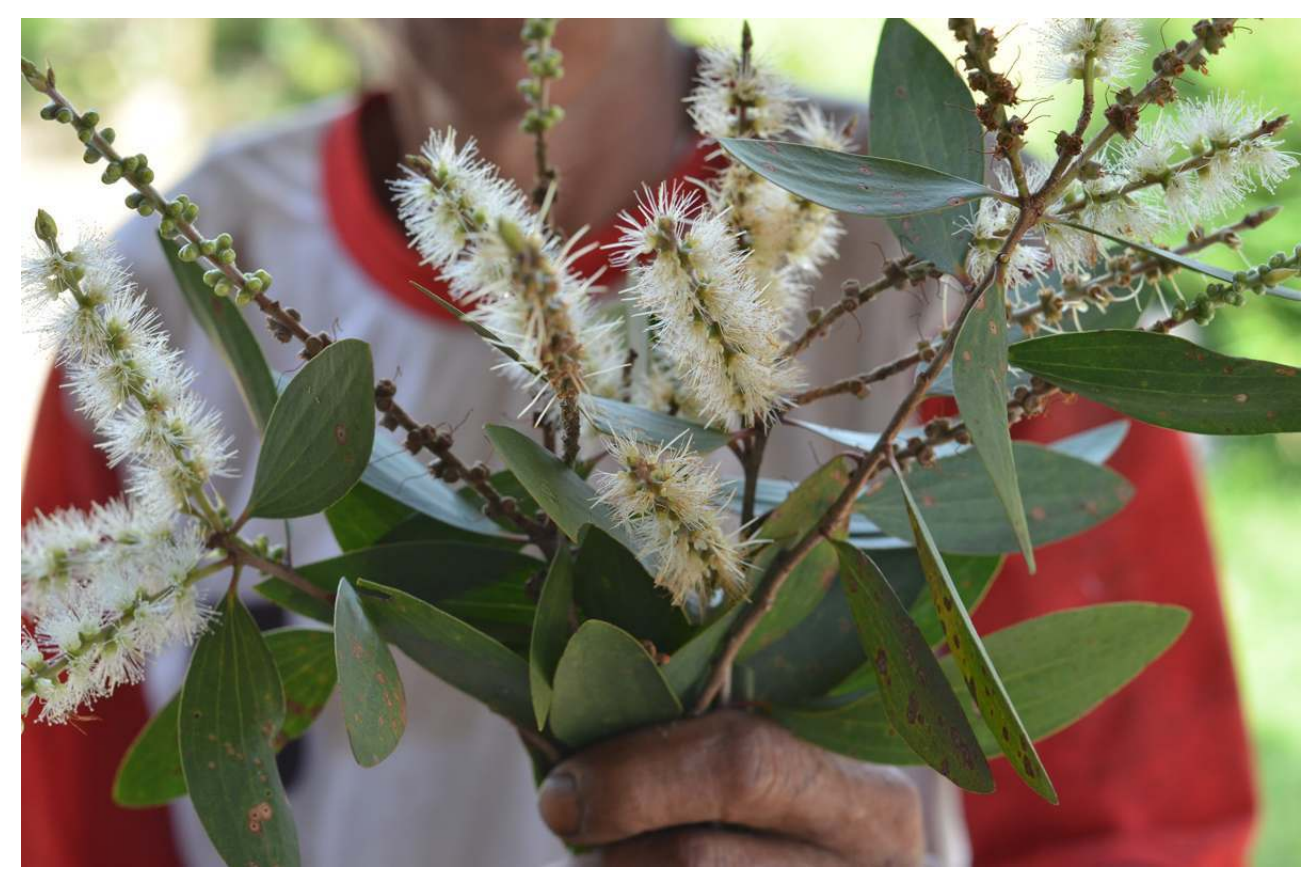

(C) N. CÉSARD

Everywhere in the Indonesian archipelago, the regularity of the main flowerings allows harvesters to anticipate the arrival of the swarms and to prepare themselves to harvest the nests. In the lake region of Sentarum, the colonies arrive from the surrounding hills in December and settle first on the tall trees (called lalau) on which their combs are collected. Then, several tree species in the flooded forests come into bloom and the swarms move onto low vegetation where they find the honey planks (called tikung) already set up. On Belitung Island, the colonies migrate regularly, especially when the main flowerings approach. According to the harvesters, some swarms come from the island's interior while others migrate from more distant regions like from the coasts of Sumatra and Borneo. As in Sentarum, the harvesters prepare themselves for the bees' arrival: between two blooms, they change the most damaged honey trunks (called sunggau), build new structures, and clean and prepare the sites by cutting and clearing away unwanted vegetation (see Césard 2015). When flowers bud, they know that the bees will begin to bring pollen to the newly built comb, and then produce honey.

\section{Understanding the development of the comb to harvest at the right time}

Whereas the placing of honey planks and tree trunks rely predominantly on ecological observations, the harvesting of honey requires harvesters to understand the development of the comb and the life cycle of the bees. On nesting sites, and when the distance allows it, harvesters regularly observe the comings and goings of the bees and their activities on the comb. They know that the bees stay on their nest during rainy days (and consume their pollen and honey stocks) and that they visit flowers during moonlit nights. Most of the observations are done on the honey planks or trunks and take place around the comb or on its surface, often at ground level. Knowledge holders combine several signs that 
they have observed during previous harvestings: pre-harvesting indicators on the comb occupied by bees, and post-harvesting indicators once the colony has been smoked and the wax cells and the brood are visible. From these indicators harvesters know when the honey harvesting can take place.

In Belitung, like in the Sentarum region, harvesters are paying attention first to blossoms. They know that the swarms arrive when the buds open and will leave again soon after the end of the flowering periods. The harvesters rely on the observation that once flowers are faded (they said once "dry up »), bees no longer seek nectar and the cells on the comb containing honey are sealed. In the flooded forests of Sentarum Lake, the harvesters are attentive to wilting and to color change, as well as to the falling of petals. Likewise, when the harvesting time approaches, direct observation of the comb gives several indications which confirm its development. By regularly viewing the occupied comb in profile, harvesters can deduce the replacement of the pollen by honey on the upper part of the comb: bees expanding the alveoli as they fill them up with honey. At a distance, they observe bee activity on and around the comb: when worker bees do not move on the pollen cells and when there is less flying back and forth, they know that the bees are not producing honey anymore and that their stocks of pollen are being depleted.

Some flowerings are too short and some harvesters have noticed that these blooms are insufficient for the colony to fully develop, and ultimately be able to reproduce. According to harvesters, bees then swarm (non-reproductive swarming) to better locations, some of which may be in neighboring areas, while others may be far more distant. Other flowerings, which are more geographically localized such as the one of the gelam trees in the south of Belitung, can last two months or even three in certain areas, and the swarms, taking advantage of the abundance of the floral resources available, produce new queens, mate and start up new colonies (reproductive swarming). Flowerings constitute the main indicator for harvesting. While the harvesters can hardly predict the abundance of blooms and their duration (they say because of changing weather conditions), they do know how the bees behave during flowerings. In particular, they know that the bees swarm quickly at the end of short flowerings, but also that they can stay on the comb and rebuild their stocks of pollen and honey if more flowers appear in the following days. This detailed observation of flowerings, of some trees in particular, but also of the ecosystem as a whole, allows harvesters to adapt their harvesting strategies to the conditions observed.

In Belitung, the most experienced individuals harvest honey at least one week after the arrival of the swarm (for those who want to harvest quickly), and always a bit before the last flowers of a bloom died. They have also observed that when a flowering lasts (the ongoing one or another one), a second harvest can take place two weeks and sometimes three weeks after the bees are settled. Based on the their observation that bees come and go with flowers, the harvesters hurry to intervene as they know that the colony in the absence of new flowers is going to deplete its pollen to feed its larvae and consume its honey to prepare for swarming. They know from experience that without a new flowering the bees will stay only a few days on the comb before leaving. The most conservative action (to obtain a maximum of honey) is then to anticipate the bees by proceeding quickly with the harvest. To do so, the harvesters smoke the bees, then take the honey at the extremity of the comb and cut the brood (which is often eaten, raw or cooked, back at home). The strategy changes if other flowerings are coming: harvesters know that if they take the honey from the comb, but leave behind the pollen and the brood, they can 
proceed to a second harvest, and even a third, since the «bees » (here the queen) lay eggs again and wait for most larvae to change into adult insects to swarm.

41 A harvester from Belitung Island sums up the relationship between the life cycle of flowers and the development of the bees with the following phrase:

«When there are a lot of flowers, there are only a few children [the young bee larvae], but when there are a few flowers, one can find many children [larvae and young adults] ».

And the time has come to harvest honey from the comb.

Figure 18 : After having cut the brood, the harvester takes the honey "head". Belitung, 2011

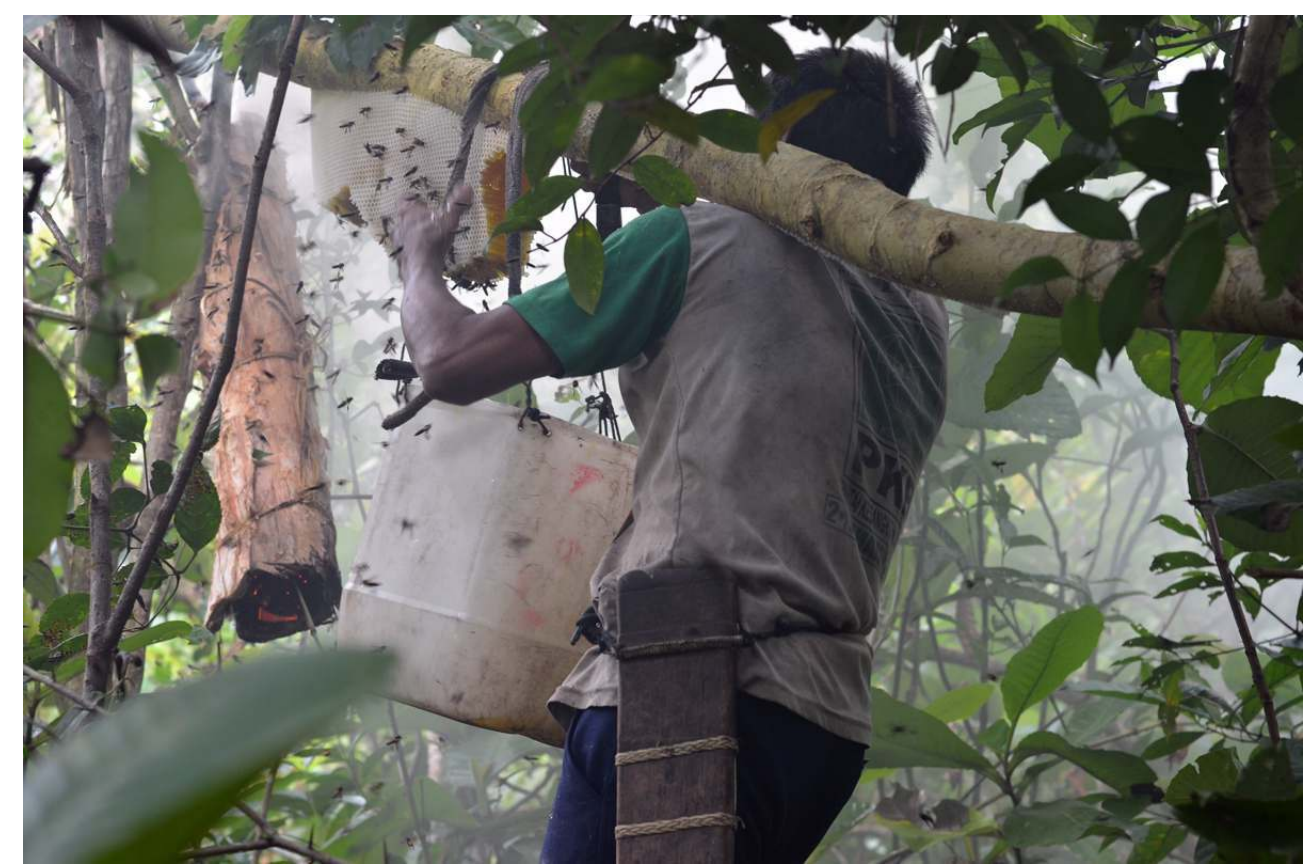

(c) N. Césard

\section{Concluding remarks}

43 What lessons can be drawn about the direct or indirect influence of indigenous and local peoples and their knowledge and practices on pollinators and the pollination process? The three cases presented here by ethnoecologists and anthropologists who have worked between 10 to 20 years with local knowledge holders illustrate the extent and the diversity of knowledge and practices in different societies about pollination and pollinators. But they provide only a glimpse of in reality thousands of different ways that peoples interact with pollinators and intervene in pollination processes around the world. These diverse relationships are as remarkable as hand pollination, which has accompanied since millennia the creation of oases in the Sahara or agroforestry systems where people and domestic bees participate together in the creation and maintenance of entire landscapes. Here the bees are the vectors between people and the plants that feed and maintain the health of humans and bees alike. Bees, whether wild or domestic, are managed to different degrees by agriculturalists, hunters or gatherers. By managing the bees, local people also influence the ecology and structure of the forest. The scale and diversity of societal relationships with pollination and pollinators are endlessly variable, 
from the indigenous Ogiek hunter-gatherers, the people of the honey in Kenya, who migrate altitudinally to follow colonies of honeybees and flowerings across their mountain territories, to modern-day beekeepers whose motorized transhumance, accompanied by their domestic honeybees, also follows the flowering of orchards and crops at the demand of industrial farming .

\section{Intentionality and the limits of 'knowledge'} culture of its own, not even shared by the majority of people in their own society, let alone other societies and cultures, and particularly indigenous peoples who have not 
developed 'science' as a separate enterprise and who observe, think, class and draw conclusions in other languages and according to other ontologies. Like all knowledge systems, science has its strengths but also its weaknesses, which become self-evident when dealing with socio-ecological complexities such as the interactions of people with their environment.

The issue of intention also needs to be put into perspective. Studies in philosophy of science have shown that many great scientific discoveries, like Pasteur's butyric acid fermentation, for instance, are the product of a mistake, an unexpected outcome. This phenomenon, referred to as serendipity, is a much more common feature of scientific practice and discovery than the majority of scientists would be happy to admit. At the same time, these results were not obtained entirely by chance. The 'discovery' occurred because research was on-going in the field, and the investigators had developed a high level of observation and reflection, and could learn from their mistakes and capitalize on chance. These observations from philosophy of science about knowledge acquisition in the sciences underscore similarities with local and indigenous knowledge systems rather than their differences. Actions that shape the interactions between pollinators and pollinated plants are part of an entire system created by a culture during centuries if not millennia. Untrained fieldworkers who ask a farmer naïve questions such as: « Are your practices meant to enhance pollination? » may not even be understood. Practices have multiple motivations and outcomes. What makes sense for a knowledge holder is the whole.

\section{Direct positive action and indirect negative action}

51 Social anthropologists specialised in the field of ethnoecology have been discussing the relationships between societies and their actions since decades. In closing it may be instructive to consider a paradigm about relationships between societies and what Westerners refer to as Nature. Haudricourt, in his pioneering paper about domestication published in 1962, states that the important distinction to be made among different types of relationships of societies with nature is not between domesticated and wild, but rather between direct positive action, such as shepherds with their sheep, and negative indirect action, such as Pacific islanders cultivating yam. In the first case the shepherds direct their herds of sheep, while in the second, the horticulturalists 'make do' or offers favourable conditions (in French faire faire). The yam is fragile and should be nurtured/ cultivated, but should not be touched directly. Indirect action has nothing to do with mere passivity. In indirect action, there is no simultaneity, or immediate effect of the actions taken. In the same way, actions on wild honeybee colonies require a lot of knowledge and care, and have a beneficial effect on pollination, although this result is far from immediate.

52 These insights are instructive for our discussion of pollination, knowledge, practice and intentionality. To make some progress in understanding indigenous and local knowledge, biologists have to practice interdisciplinarity or at least to privilege qualitative rather than quantitative social sciences. They need to accept the diversity of practices among societies, and to stop believing that only direct positive action, which could be seen as the essence of an industrial society obsessed by cost efficiency, can be the source of an intentional action on pollination and therefore of the understanding by local peoples of this phenomenon. 
The authors would like to thank the people of the Siwa Oasis (Egypt), Essaouira, Agadir, Sidi Ifni and Guelmim (Morocco), Belitung Island and Danau Sentarum (Indonesia), who kindly shared their knowledge. Romain Simenel would like to thank the program SENTIMIEL of the French Institute of Research for Development (IRD) (with support from the Biodiversity Research Foundation) and the LMI Mediter (IRD/University Mohammed V Rabat-Agdal/University Cadi Ayyad Marrakech). His work is the result of a collective research based on a partnership between Moroccan and French researchers: Antonin Adam (IRD), Audrey Croussilles (Faculté de Pharmacie de Montpellier), Lahoucine Amzil (Université Mohamed V Agdal, CERGEO) and Yildiz Aumeeruddy-Thomas (CNRS/ UMR CEFE 5175), coauthors of the article: La domestication de l'abeille par le territoire: un exemple d'apiculture holiste dans le sud marocain. Techniques et Culture 63 : 258-279, June 2015. The authors thank Douglas Nakashima for his remarkable editing and rewriting in English.

\section{BIBLIOGRAPHY}

Abedi A., Karimian S.M., Parviz M., Mohammadi P. \& Roudsari H.R.S. 2014 - Effect of Aqueous Extract of Phoenix dactylifera Pollen on Dopamine System of Nucleus Accumbens in Male Rats. Neuroscience \& Medicine 5 : 49-59. En ligne : http://dx.doi.org/10.4236/nm.2014.51008

Appanah S. 1985 - General flowering in the climax rain forests of South-East Asia. Journal of Tropical Ecology $1: 225-240$.

Baroin C. \& Pret P.-F. 1993 - Le palmier de Borkou, végétal social total. Journal des Africanistes LXIII (63) : 5-20. En ligne : http://www.persee.fr/web/revues/home/prescript/article/ jafr_0399-0346_1993_num_63_1_2369

Battesti V. 2004 - Odeur sui generis : le subterfuge dans la domestication du palmier dattier (Tassili n'Ajjer, Algérie). In Bonte P., Brisebarre A.-M., Helmer D. \& Maamar H. S. (Ed.)

Domestications animales : dimensions sociales et symboliques (Hommage à Jacques Cauvin), numéro de Anthropozoologica. Paris, Publications Scientifiques du Muséum 39 (1) : 301-309. En ligne : http://hal.archives-ouvertes.fr/halshs-00004025

Battesti V. 2005 - Jardins au désert, Évolution des pratiques et savoirs oasiens. Jérid tunisien. Paris, Éditions IRD, 440 p. En ligne : http://hal.archives-ouvertes.fr/halshs-00004609

Battesti V. 2013 - L'agrobiodiversité du dattier (Phoenix dactylifera L.) dans l'oasis de Siwa (Égypte) : entre ce qui se dit, s'écrit et s'oublie. Revue d'ethnoécologie 4 (Le palmier dattier : Origine et culture en Égypte et au Moyen-Orient / The Date Palm: Origin and Cultivation in the Middle East and in Egypt). En ligne : http://ethnoecologie.revues.org/1538

Césard N. 2015 - Les Fermiers du miel. Apicollecte et apiculture à Belitung, Indonésie. 38 min. SMM CNRS MNHN. Vidéo en ligne : http://www.canal-u.tv/video/smm/

les_fermiers_du_miel_apicollecte_et_apiculture_a_belitung_indonesie.17039

Chao C.T. \& Krueger R.R. 2007 - The Date Palm (Phoenix dactylifera L.): Overview of Biology, Uses, and Cultivation. HortScience 42 (5) : 1077-1082.

De Vries R. 1990 - The history of honey and wax production of the giant honey bee (A. dorsata) in Sumatra and Kalimantan, Indonesia. Proceedings of the first Nectar Seminar, Amsterdam : 75-85. 
Gros-Balthazard M., Newton C., Ivorra S., Tengberg M., Pintaud J.-C. \& Terral J.-F. 2013 - Origines et domestication du palmier-dattier (Phoenix dactylifera L.) : état de l'art et perspectives d'étude. Revue d'ethnoécologie 4 (Palmiers dattiers et palmeraies au Proche-Orient : origine et culture / Date palms and palm groves in the Near-East: Origin, and culture). En ligne : http:// ethnoecologie.revues.org/1524

Giovino M. 2007 - The Assyrian Sacred Tree: A History of Interpretations. Fribourg (Suisse), Göttingen, Academic Press Fribourg, Vandenhoeck Ruprecht, Orbis biblicus et orientalis 230, viii-242 p.

Hadisoesilo S. 2001 - Tingku, a traditional "Management" technique for Apis dorsata binghami in Central Sulawesi, Indonesia. In International Bee Research Association (Ed.) Proceedings of the Seventh International Conference on Tropical Bees: Management and Diversity : 309-312.

Hassan W.A., El-kashlan A.M. \& Ehssan N.A. 2012 - Egyptian Date Palm Pollen Ameliorates Testicular Dysfunction Induced by Cadmium Chloride in Adult Male Rats. Journal of American Science 8 (4) : 659-669.

Haudricourt A.-G. 1962 - Domestication des animaux, culture des plantes et traitement d'autrui. L'Homme, 2 (1) : 40-50. En ligne : /web/revues/home/prescript/article/ hom_0439-4216_1962_num_2_1_366448. Consulté le 25 juin 2015

Kasina M., Kraemer M., Martius C. \& Wittmann D. 2009 - Farmers' knowledge of bees and their natural history in Kakamega district, Kenya. Journal of Apicultural Research 48 : 126-133

Landsberger B. 1967 - The date palm and its by-products according to the cuneiform sources. Selbstverlag des Herausgebers, Archiv für Orientforschung, Beiheft, 17

Latour B. 1983 - Comment redistribuer le Grand Partage. Revue de Synthèse 110, Avril/Juin : 203-236 [Reprint in La Revue du Mauss N¹, pp. 27-65, 1988].

Michel-Dansac F. \& Caubet A. 2013 - L'iconographie et le symbolisme du palmier dattier dans l'Antiquité (Proche-Orient, Égypte, Méditerranée orientale). Revue d'ethnoécologie 4 (Palmiers dattiers et palmeraies au Proche-Orient : origine et culture / Date palms and palm groves in the Near-East: Origin, and culture). En ligne : http://ethnoecologie.revues.org/1275

Mulder V., Heri V. \& Wickham T. 2000 - Traditional honey and wax collection with Apis dorsata in the upper Kapuas lake region, west Kalimantan. Borneo Research Bulletin $31: 246-260$.

Neumann P., Koeniger N., Koeniger G, Tingek S, Kryger P \& Moritz R.F. 2000 - Home-site fidelity in migratory honeybees. Nature 406 (6795) : 474-475.

Nixon R.W. 1926 - Experiments with selected pollens. Date Growers' Inst. Rep. 3 : 11-14.

Nixon R.W. 1927 - Further evidence of the direct effect of pollen on the fruit of the date palm. Date Growers' Inst. Rep. 4 : 7-9.

Paar J., Oldroyd B.P. \& Kastberger G. 2000 - Giant honeybees return to their nest sites. Nature 406 (6795) : 475.

Popenoe P.B. \& Bennett C.L. 1913 - Date growing in the old world and the new [with a chapter on the food value of the date]. Altadena, Cal., West India Gardens, 316 p. En ligne : http:// www.archive.org/details/dategrowinginoldo0poperich

Riou C. 1990 - Bioclimatologie des oasis. In Toutain G. \& Dollé V. (Ed.) Les systèmes agricoles oasiens, Actes du colloque de Tozeur (19-21 nov. 1988). Montpellier, CIHEAM, Options méditerranéennes, Série A : Séminaires Méditerranéens 11 : 207-220. En ligne : http://om.ciheam.org/om/pdf/a11/ CI901496.pdf 
Sakai S. 2002 - General flowering in lowland mixed diterocarp forests of South-east Asia. Biological Journal of the Linnean Society 75 : 233-247.

Simenel R. 2011 - Les miels des forêts d'arganiers. Dossier thématique de l'IRD - « Suds en ligne » intitulé « Des forêts et des hommes ». En ligne : http://www.mpl.ird.fr/suds-en-ligne/foret/ index.html

Simenel R. et al. 2015 - La domestication de l'abeille par le territoire : un exemple d'apiculture holiste dans le sud marocain. In Techniques et Culture 63 Pâturages.

Swingle W.T. 1928 - Metaxenia in the date palm. Journal of Heredity 19 (6) : 257-268.

Tengberg M. 2012 - Beginnings and early history of date palm garden cultivation in the Middle East. Journal of Arid Environments 86 (November 2012, Ancient Agriculture in the Middle East) : 139-147. En ligne : http://dx.doi.org/10.1016/j.jaridenv.2011.11.022

Tengberg M., Battesti V. \& Newton C. (Ed.) 2013 - Le palmier dattier : origine et culture en Égypte et au Moyen-Orient / The Date Palm: Origin and Cultivation in the Middle East and in Egypt. Revue d'ethnoécologie 4. En ligne : http://ethnoecologie.revues.org/1216

\section{NOTES}

1. Coordination by Marie Roué; case studies by Vincent Battesti (Egypt), Nicolas Césard (Indonesia) and Romain Simenel (Morocco); English rewriting by Douglas Nakashima.

2. Some recent research is aimed at demonstrating the aphrodisiac qualities of date palm pollen using animal tests (see for example Hassan et al. 2012 ; Abedi et al. 2014).

3. The materials presented in this paper were collected during several field trips between 2008 and 2012 in the region of Essaouira, Agadir, Sidi Ifni and Guelmim. The three tribal groups with whom interviews were conducted are Haha, Ida or Tanan and Ait Ba'amran, all Tachelhit speakers, a Berber dialect of South Morocco. Most interviews with beekeepers were performed in Tachelhit or dialectal Arabic. We benefited from the experience and knowledge of beekeepers Lahoucine Bounnit, Mohamed Sforge and Salah Sayed, whom we thank.

\section{ABSTRACTS}

This paper brings together three case studies on the interrelationships amongst people, pollination processes and pollinators (notably honeybees). In the palm groves of Saharan oases, the milieu and varieties of palm trees are created by horticulturalists, who fulfil themselves the role of pollinators. In southern Morocco, entire landscapes, including in particular the agroforests of argan trees, are the products of a remarkable symbiosis between bees and people. In Indonesia, honey harvesters have an exacting local knowledge of the giant honeybees and the timing and nature of blooms. They use this knowledge to attract migratory swarms and to decide the optimal moment to harvest honey so that the bees are incited to return.

The authors, specialists in social system/ecosystem interactions, decided to pool their expertise so as to render more accessible their research results, which are often dispersed amongst journals specialized in different cultural areas. By focusing their analyses instead on an 
important biological phenomenon threatened by human action (in this case, pollination), they hope that their audience will also include biologists, policy makers and environmental managers. Given the growing diversity and complexity of threats facing biodiversity, the responses proposed by conservation biology alone are often inadequate. To understand the dynamics of anthropo-ecosystems, the outcomes of a long co-evolutionary process involving a wide range of living beings, an interdisciplinary approach is mandatory. Conservation and sustainable use cannot be achieved without an understanding of local people's knowledge and practices, a prerequisite for establishing in partnership with them, protection measures that are both respectful and locally adapted.

Cet article réunit trois études de cas concernant les relations entre les hommes, les processus de pollinisation, et les pollinisateurs (ici les abeilles mellifères). Dans les palmeraies des oasis du Sahara, milieu et variétés sont créés par des horticulteurs qui jouent eux-mêmes le rôle du pollinisateur ; dans le sud marocain, le paysage tout entier, tout particulièrement celui des arganeraies, est le résultat d'une remarquable symbiose entre les abeilles et les hommes; en Indonésie, les collecteurs de miel possèdent un savoir local précis de l'abeille géante et des floraisons qu'ils utilisent pour attirer les essaims migratoires et récolter le miel au meilleur moment tout en facilitant leur retour.

Les auteurs, spécialistes des relations Nature/Sociétés ont souhaité, en mettant en commun leur expertise, rendre leurs résultats accessibles, car ils étaient souvent dispersés dans diverses publications spécialisées liées à une aire culturelle. En concentrant leur analyse sur un phénomène biologique important menacé par l'action de l'homme, ils entendent s'adresser aux biologistes, décideurs et gestionnaires. Face aux menaces qui pèsent sur la biodiversité, la biologie de la conservation se trouve prise au dépourvue. La compréhension des anthropoécosystèmes, dont l'état actuel est lié à un processus de coévolution entre tous les êtres vivants, impose une démarche interdisciplinaire. Leur conservation ne peut être assurée sans que l'on comprenne les pratiques et les savoirs des peuples locaux, pour pouvoir mettre en place avec eux des mesures de protection respectueuses et localement adaptées.

\section{INDEX}

Keywords: Indigenous and Local Knowledge (ILK), pollinators, pollination, honeybee, handpollination, Apis mellifera, Apis dorsata, domestication, varroa, direct positive action, indirect negative action, honey collecting

Mots-clés: savoir local et autochtone (SLA), pollinisateurs, pollinisation, abeille, pollinisation manuelle, Apis mellifera, Apis dorsata, domestication, varoa, action positive directe, action négative indirecte, apicollecte, apiculture

Geographical index: Indonésie, Maroc, Sahara

\section{AUTHORS}

\section{MARIE ROUÉ}

Directrice de Recherches émérite, CNRS/MNHN

Laboratoire d'Éco-anthropologie et Ethnobiologie

Muséum national d'Histoire naturelle

Musée de l'Homme

17 place du Trocadéro 
75116 PARIS

roue@mnhn.fr

\section{VINCENT BATTESTI}

Chargé de Recherches, CNRS/MNHN

Laboratoire d'Éco-anthropologie et Ethnobiologie

Muséum national d'Histoire naturelle

Musée de l'Homme

17 place du Trocadéro

75116 PARIS

Department of Anthropology

Columbia University, New York

x@vbat.org

\section{NICOLAS CÉSARD}

Chercheur associé

Laboratoire d'Éco-anthropologie et Ethnobiologie

Muséum national d'Histoire naturelle

Musée de l'Homme

17 place du Trocadéro

75116 PARIS

ncesard@mnhn.fr

ROMAIN SIMENEL

Ethnologue

PALOC (UMR 208), IRD

romain.simenel@ird.fr 